\title{
PROTECCIÓN DE INTERESES JURÍDICOS SUPRAINDIVIDUALES: ACTUACIÓN DE LAS ADMINISTRACIONES PÚBLICAS, JUSTICIA CIVIL Y COMBINACIÓN DE SISTEMAS DE PROTECCIÓN*
}

\author{
Manuel Ortells Ramos ${ }^{* *}$
}

\section{Delimitación del tema y algunas Cuestiones de métOdo}

\section{Justificación del contenido de la ponencia}

La selección de los contenidos que trato en la ponencia ${ }^{1}$, de los que la tabla correspondiente ofrece una visión panorámica, se debe a dos clases de razones.

De entrada, he tenido presentes los matices diferentes que resultan de los títulos de la ponencia en tres idiomas. "Private Justice (Private Law Enforcement)" es impreciso en su significado literal, aunque no en el contexto de la cultura jurídica estadounidense, y alude tanto a la naturaleza de la autoridad de aplicación del Derecho, cuanto a la calidad de quien puede requerir esa aplicación. "Justice Privée (Poursuite privée de la loi)" centra la atención en el poder (privado) de iniciativa para la aplicación del Derecho. El título en alemán -“Durchsetzung öffentlicher Interessen im Zivilprozess" - destaca tanto la calidad de los intereses protegidos -intereses públicos-, como el instrumento de protección -el proceso civil-.

Por otra parte, diversas normas de Derecho europeo dejan en manos de los ordenamientos estatales la atribución de las potestades de aplicación de normas que protegen intereses supraindividuales a autoridades administrativas o a órganos jurisdiccionales ${ }^{2}$. Esta solución revela cierta duda sobre la opción más

\footnotetext{
* Ponencia General presentada en el XIV Congreso Mundial de Derecho Procesal, Actuación del Derecho a instancia privada. Colaboración recibida el 30 de agosto y aprobada el 20 de septiembre de 2011.

** Catedrático Universidad de Valencia, España. Correo electrónico: manuel.ortells@uv.es

1 La elaboración de esta ponencia y su presentación en el Congreso han contado con la financiación del Ministerio de Ciencia e Innovación del Gobierno de España (Proyecto DER 2008-03240).

2 Puede encontrarse una útil exposición resumida en HodGes, CH., "Global Class Actions Project. Summary of European Union Developments", The Globalization of Class Actions, International Conference co-sponsored by Standford Law School and the Centre for Socio-Legal Studies, Oxford University, 13-14 December 2007, disponible en http://www.law.stanford.edu/calendar/details/1066/\#related_media.
} 
idónea, que también se manifiesta en el debate abierto en la Unión Europea acerca de las autoridades -administrativas o jurisdiccionales- que deben aplicar el Derecho de la Competencia y el Derecho que protege a consumidores y usuarios, así como acerca de quién ha de tener el poder de iniciativa para instar la actuación del Derecho y qué clase de protección jurídica puede obtener ${ }^{3}$. En el plano académico son abundantes los escritos que analizan y valoran las opciones del public y del private enforcement de diversos sectores del Derecho ${ }^{4}$. Este debate constituye un buen indicador de los principales contenidos de la ponencia, aunque ésta debe ir más allá de los términos de aquél.

\section{Cuestiones de método y técnica de trabajo. En especial, la colaboración de los ponentes nacionales}

El tema no puede ser suficientemente tratado como una materia de Derecho Procesal y con el método adecuado para la misma. Están implicados aspectos de Derecho Constitucional y de Derecho Administrativo. Incluso la materia procesal debe ser concebida con amplitud.

En segundo lugar, juegan también un papel importante técnicas no imperativas de solución de conflictos como el arbitraje, la mediación, la conciliación y otras. A veces la efectividad de estas últimas depende de que los sujetos en conflicto tengan presente que las técnicas de resolución imperativa -con sus

\footnotetext{
3 Véase, p. ej., en materia de Derecho de la Competencia, White Paper on Damages actions for breach of the EC antitrust rules. Brussels, 2.4.2008. COM(2008) 165 final, y la Communication from the Commission to the European Parliament and the Council. Report on the functioning of Regulation 1/2003. Brussels, 29.4.2009. COM(2009) 206 final. En materia de actuación de normas protectoras de consumidores y usuarios, Green Paper on Consumer Collective Redress, Brussels, 27.11.2008. COM(2008) 794 final, así como la Communication from the Commission to the European Parliament, the Council, the European Economic and Social Committee and the Committee of the Regions on the Enforcement of the Consumer Acquis. Brussels, 2.7.2009. COM(2009) 330 final.

${ }^{4}$ Sin ninguna pretensión de exhaustividad, con carácter más general, HodGes, CH., The Reform of Class and Representative Actions in European Legal Systems. A New Framework for Collective Redress in Europe, Hart Publishing, 2008. Respecto del Derecho de la Competencia, HodGes, CH., "Competition Enforcement, Regulation and Civil Justice: What's the Case", en Common Market Law Review, Oct 2006, 43, pp. 1381-1407; Eger, TH., WeISE, P., "Limits to the private enforcement of antitrust law", disponible en http://www.cbs.dk/content/download/67269/930127/file/Thomas\%20Eger.doc.; SALERNO, F. M., "The Competition Law-ization of Enforcement: The Way Forward for Making The Energy Market Work?", EUI Working Papers, RCSCAS, 2008/07; Alfaro ÁGUILA-REAL, J., "Contra la armonización positiva: la Propuesta de la Comisión para reforzar el private enforcement del Derecho de la Competencia, en InDret. Revista para el Análisis del Derecho (www.indret.com), Julio, 2009, pp. 2-35; Möllers, Th. M. L., Heinemann, A., Eds., The Enforcement of Competition Law in Europe, Cambridge University Press, New York, 2009. En materia de protección de los consumidores, CAFAGGI, F., MICKLITZ, H-W, "Administrative and Judicial Collective Enforcement of Consumer Law in the US and the European Community", EUI Working Papers, Law 2007/22; CAFAGGI, F., MICKLITZ, H-W, "Administrative and Judicial Enforcement in Consumer Protection: The Way Forward", EUI Working Papers, Law 2008/29; así como los trabajos de esos mismos autores y de otros en la obra colectiva editada por CafaGgI, F., MickLITZ, H-W, Eds., New Frontiers of Consumers Protection. The Interplay between Private and Public Enforcement, Intersentia, 2009.
} 
efectos, a veces inconvenientes y no deseados- siempre "planean" sobre los conflictos. Para profundizar en esto las consideraciones jurídicas no bastan, sino que hay que atender a apreciaciones de orden económico, sociológico y de psicología social.

Por fin, el análisis y evaluación de los sistemas de actuación del Derecho depende -después de que la ciencia jurídica haya servido para entender su estructura y el funcionamiento formales- de consideraciones económicas ${ }^{5}$, sociológicas, de psicología social y, en definitiva, históricas, por cuanto la actitud de los miembros de los diversas sociedades ante los sistemas de actuación del Derecho que las rige responde, en buena medida, a condicionamientos fácticos e ideológicos gestados históricamente y que permanecen o evolucionan con distintos tempos.

El bagaje de información y de conocimiento de métodos adecuados para tratarla con plenitud es tan exigente que lo honesto es reconocer que esta ponencia sólo podrá ofrecer una aproximación al tema que constituye su objeto.

Por fin, unas palabras sobre la técnica de trabajo. Dirigí mi cuestionario-que redacté tras un estudio preliminar- a diversos colegas que desarrollan su labor académica en países que pueden encuadrarse en el sistema de civil law. Mi invitación fue aceptada por la mayor parte de sus destinatarios. La colaboración que les pedí requería un notable esfuerzo. Por eso mi agradecimiento es también grande para Andrea A. Meroi, Profesora Titular de Derecho Procesal, Universidad Nacional de Rosario (ARGentinA), Juan Bautista Parada Caicedo, profesor de universidad y miembro de la Academia Colombiana de Jurisprudencia (COLOMBIA) -que ha tenido la colaboración del Dr. Bernardo Florez Ruiz, juez administrativo-, Soraya Amrani Mekki, Professeur Université Paris I Panthéon-Sorbonne (FrANCIA) -que, en algún apartado, ha tenido la colaboración de Frédéric Rolin-, el Prof. Dr. Giorgios Orfanidis, de la Universidad de Atenas (GReCIA), Michele Angelo Lupoi, Profesor de la Universitá degli Studi de Bologna (ITALIA) -que ha contado con la colaboración de las Dras. Caterina Pasini y Teresa Vestrucci-, Manabu Honma, Associate Professor, Law Faculty of Tezukayama University (JAPÓN), Robert Kulski, Profesor en la Universidad de Łód (POLONIA), y Maria Filatova, Associate Professor at the Russian Academy of Foreign Trade, Deputy Director of the Russian Constitutional Court Representative Office in Moscow (Rusia). Antonio Gidi, Ass. Professor University of Houston, Law Center, no pudo preparar el informe nacional sobre BRASIL, pero me remitió amablemente un amplio material bibliográfico. A todos ellos les pido, también, disculpas

\footnotetext{
5 Y las apreciaciones económicas son de índole bastante diversa: aspectos de microeconomía -p. ej., valoración de la oportunidad de iniciar un proceso en atención a su coste y a las expectativas de resultados-, de economía de las finanzas públicas -eficiencia del gasto público según los diversos sistemas de actuación del Derecho-, y la perspectiva macroeconómica -incidencia de esos sistemas sobre la economía general-.
} 
porque los límites de extensión de esta ponencia no me han permitido reflejar la riqueza de sus aportaciones.

Para llenar vacíos de información he utilizado, también, además de otra bibliografía que se verá citada en la ponencia, el UNCTAD Guidebook on Competition Systems, United Nations, New York and Geneva, 2007, que reúne una información sintética sobre los sistemas de aplicación del Derecho de la Competencia a nivel mundial, y, también de la UNCTAD, la Model Law on Competition. Substantive Possible Elements for a Competition Law, Commentaries and Alternative Approaches in Existing Legislation, United Nations, New York and Geneva, 2010, buen indicador de problemas y de cuestiones debatidas, principalmente en los comentarios al texto de ley modelo en elaboración. También he utilizado ampliamente las aportaciones académicas y la información legislativa recogidas en The Globalization of Class Actions, International Conference co-sponsored by Standford Law School and the Centre for Socio-Legal Studies, Oxford University, 13-14 December 2007, organizada por la Prof. Deborah Hensler y por el Dr. Christopher Hodges ${ }^{6}$.

\section{UNA NUEVA REALIDAD SOCIAL Y ECONÓMICA, UN NUEVO DERECHO Y SU INCIDENCIA SOBRE LAS INSTITUCIONES ENCARGADAS DE SU ACTUACIÓN}

\section{Nueva realidad y nuevo Derecho}

El Derecho que rige las relaciones entre los miembros de la sociedad civil (políticamente organizada en un Estado o en otra estructura política) ha experimentado importantes transformaciones si se compara con la situación de finales del siglo XIX y principios del XX.

La regulación es más abundante y alcanza a los ámbitos más diversos de la vida social. La causa principal radica en las importantes transformaciones producidas en la realidad social regulada, debidas al desarrollo social, económico y tecnológico. Esa realidad ha transitado desde un estadio en el que predominaban las relaciones jurídicas singularizadas y aisladas entre sí, hacia otro estadio caracterizado por el predominio de relaciones jurídicas masivas, de situaciones jurídicas que afectan a conjuntos más o menos amplios de personas.

A) Concienciación de los derechos de la personalidad y de los derechos civiles y nuevos riesgos para los mismos

Existen potentes procesos de toma de conciencia y de autoafirmación de los derechos civiles por grupos sociales que estuvieron sometidos a trato discriminatorio y que se hallan expuestos a la continuidad de ese trato o a riesgos de vuelta atrás. Esto explica legislaciones de protección de la igualdad frente a

${ }^{6}$ Los materiales de este congreso los cito por los documentos que están disponibles en http://www. law.stanford.edu/calendar/details/1066/\#related_media. 
discriminación por diversas causas (raza, género, religión, discapacidad, etc.) y en diversos ámbitos de la vida social (relaciones laborales, acceso a los bienes y servicios públicos, etc.).

Crece la necesidad de protección de los derechos de la personalidad -derecho a la intimidad personal y familiar- especialmente amenazados por avances tecnológicos de amplio potencial lesivo. Esto justifica una regulación de protección frente a conductas ilegítimas en el tratamiento automatizado de datos de carácter personal.

B) Actividad contractual masiva

En el plano patrimonial la nueva realidad se caracteriza por una actividad contractual masiva con diferentes manifestaciones:

1) La producción industrial en masa, acompañada de la fuerte explotación de los recursos naturales, hace necesario el establecimiento de vínculos contractuales abundantes para relacionar a los distintos agentes de los procesos productivos, y a la estandarización de esos vínculos para optimizar los resultados.

2) Entre esos vínculos contractuales destacan los que regulan las relaciones laborales, necesariamente masificadas por los niveles de producción de bienes y servicios que se persigue alcanzar. Ligadas a esas relaciones aparecen otras -también masivas- para la protección frente a diversos riesgos relacionados con el trabajo.

3) La producción industrial en masa va acompañada de procesos de comercialización también masificados y que tienden a los estándares contractuales.

4) El sector económico de los servicios -más allá de la comercialización de productos manufacturados- se ha desarrollado también con las mismas características de masificación y tendencia a la estandarización contractual (transportes, turismo, servicios de telecomunicaciones, y, muy destacadamente, por su importancia sistémica, los servicios financieros).

5) Obviamente, la masificación en la etapa de generación de bienes y servicios va dirigida a una última serie de operaciones contractuales masivas de adquisición de los mismos por los consumidores y usuarios.

Esas realidades generan unas necesidades de regulación que son atendidas en cada ordenamiento por normas que, obviamente con grandes diferencias en cuanto a la delimitación de las materias reguladas y en cuanto al sentido de la regulación, suelen versar sobre las relaciones laborales y de seguridad social vinculada a las mismas, las condiciones generales de la contratación -con una regulación que protege a los agentes económicos (fabricantes y prestadores de servicios) y a los consumidores y usuarios- y un régimen general de protección de los consumidores y usuarios. También son objeto de regulación más especializada -con fines de protección de diferentes agentes económicos, entre ellos, principalmente, de los consumidores- la prestación de servicios de telecomunicaciones, el mercado de la energía eléctrica y gasística, la actividad de 
entidades dedicadas a servicios crediticios, a la gestión de fondos de inversión colectiva -especialmente de fondos vinculados a planes de pensiones-, las actividades de emisión y negociación de instrumentos financieros en mercados de valores, y, cerrando un intento no exhaustivo de enumeración, la prestación de servicios de seguro.

C) El orden público económico y los fenómenos de responsabilidad extracontractual de alcance masivo

El sistema económico precisa de unas reglas objetivas para garantizar su buen funcionamiento, cuya infracción también tiene una potencialidad lesiva de amplio espectro. Los ordenamientos responden a esta necesidad principalmente mediante un régimen de prohibición de conductas contrarias a la libre competencia, destinado a proteger el buen orden de la economía, a los agentes económicos y a los consumidores y usuarios. A veces, también mediante un régimen de ilicitud de actividades publicitarias con determinadas características.

Por otra parte, la explotación intensiva de recursos naturales y determinadas tecnologías utilizadas en los procesos productivos, crean riesgos que amenazan a amplios grupos de población. De ahí, la necesidad de ordenaciones de protección del ambiente y sobre la explotación de la energía nuclear.

En fin, los avances tecnológicos, al tiempo que posibilitan la producción de efectivas sustancias curativas, pueden crear riesgos colaterales para la salud, lo que aconseja establecer un régimen específico de producción y comercialización de sustancias que puedan afectar a la salud pública. También son razones de salud pública las que, a partir de los conocimientos adquiridos mediante el progreso científico, justifican una regulación limitativa del consumo público del tabaco.

\section{Las respuestas de los Estados: normas y modalidades de actuación de las mismas}

Los Estados, y otras estructuras políticas de ámbito supra-estatal, han afrontado y afrontan estas realidades penetrando, con grados diversos de intensidad, en las relaciones jurídicas entre las personas que integran la sociedad civil.

Un primer paso consiste en el establecimiento de normas jurídicas rectoras de esas relaciones. Dentro de esta primera respuesta hay grados diferentes. Cabe una legislación cuyo alcance objetivo sea muy limitado y deje un amplio ámbito a la libre autodeterminación de las personas; o, diferentemente, una legislación omnipresente en todos los ámbitos de vida social. El Estado también puede optar por una legislación en la que predominen las normas imperativas, o por una legislación en la que abunden las normas supletorias de la autonomía de la voluntad de los particulares.

Establecidas las normas, en un segundo escalón se plantean las alternativas acerca de quién y cómo ha de actuar esas normas. 
De entrada, y en principio, el Estado más neutral frente a las relaciones jurídicas entre las personas que integran la sociedad civil estará sujeto, siempre y como mínimo, al imperativo constitucional de crear y dar acceso a instituciones judiciales para la justa resolución de las controversias que se susciten.

No obstante, si los intereses protegidos por el Derecho son intereses colectivos o sociales de diversa amplitud o son intereses públicos o generales, como es frecuente que ocurra con el Derecho que rige una realidad social de las características que antes hemos apuntado, son necesarias ulteriores especificaciones acerca de la actuación del Derecho por los tribunales, e incluso pueden ser establecidas modalidades de actuación no judiciales.

Específicamente:

1) Si la opción ha sido la de encomendar la actuación del Derecho a los tribunales de justicia, un principio de coherencia impone una correlación entre la calidad -individual, colectiva o social, general o pública- del interés protegido por la norma, y la calidad de la persona o entidad investida del poder de iniciativa para que los tribunales actúen esa norma en un caso concreto. Carecería de sentido que la actuación del Derecho protector de intereses sociales, colectivos, y generales o públicos se hiciera depender de la decisión exclusiva y excluyente de un individuo.

2) Por otro lado, si está en juego la protección de los intereses últimamente mencionados, el Estado puede avanzar más allá de la atribución a una entidad social o pública de la iniciativa para obtener la protección judicial. Puede asumir él mismo -a través del Poder Ejecutivo y de la Administración pública- la función de imponer el cumplimiento de las normas legales mediante poderes de autorización o de prohibición de actividades, acompañados de poderes de sanción a quien haya realizado actividades no autorizadas o prohibidas. Y la Administración puede imponer sus resoluciones sin necesidad de acudir, por regla general, a los tribunales de justicia. Éste es un modelo de actuación del Derecho que corresponde a la tradición jurídica de los países europeos de Derecho continental, aunque no sólo a ellos como se verá, y sobre el que $\mathrm{H}$. KELSEN teorizó calificándolo como "administración indirecta" ${ }^{7}$.

\section{LA ACTUACIÓN POR LAS ADMINISTRACIONES PÚBLICAS DEL DERECHO QUE PROTEGE INTERESES SUPRAINDIVIDUALES: CUESTIONES, RESPUESTAS Y SILENCIOS EN DIVERSOS ORDENAMIENTOS}

Una primera parte de mi cuestionario ha estado dirigida a precisar respecto de qué materias jurídicas, con normas que protegen intereses supraindividuales, se atribuye la potestad de actuación a las Administraciones públicas. He planteado

7 H. Kelsen, Teoría General del Derecho y del Estado, utilizo una edición de México, 1969, (trad. García Máinez, E.), pp. 323-334. 
una constelación de cuestiones sobre la calidad de la autoridad administrativa competente, las potestades de esa autoridad -qué efectos jurídicos puede producir su ejercicio-, la efectividad del ejercicio de tales potestades, y su utilidad para los titulares de los intereses protegidos. También he solicitado información sobre las matizaciones a la efectividad de esta modalidad de actuación debidas al control jurisdiccional de las Administraciones públicas. En fin, he pedido opinión acerca de la eficiencia (relación coste-resultado) de esta modalidad de actuación del Derecho, en términos de eficiencia del gasto público destinado a su financiación y en atención a su incidencia sobre la economía.

1. Materias jurídicas en las que las Administraciones públicas tienen atribuidas potestades de actuación del Derecho

Tomando como referencia el elenco de materias jurídicas que he expuesto en el anterior apartado II.1, los ponentes nacionales no han expresado divergencias sustanciales. Unos confirman la coincidencia en lo esencial ${ }^{8}$, o presentan una enumeración que demuestra la coincidencia ${ }^{9}$. Otros han optado por destacar las materias paradigmáticas en su ordenamiento nacional ${ }^{10}$, que coinciden con las principales de la relación más específica del apartado II.1. Especialmente el informe sobre Rusia resalta la gran amplitud de materias sobre las que recaen potestades administrativas de actuación del Derecho ${ }^{11}$.

\section{2. ¿Administraciones públicas ordinarias o autoridades administrativas independientes?}

Tiene interés la información acerca de si las potestades de protección de intereses supraindividuales son atribuidas a la que podemos Ilamar Administración ordinaria -de estructura jerarquizada y dependiente de la dirección política del Poder Ejecutivo- o a autoridades administrativas independientes que, sin perjuicio de una extraordinaria diversificación, están menos o más alejadas de esa dirección.

Un estatuto de independencia e imparcialidad de estas autoridades y las cualidades técnicas, científicas o de experiencia que son requeridas de quienes desempeñan sus funciones en las mismas, influyen en que el ejercicio de las

\footnotetext{
8 Merol, Informe Argentina; AmRani MeKkI, Rapport France.

9 Parada Caicedo, Informe Colombia.

10 Amrani MeKki, Rapport France; Honma, Japan Report; Kulski, Poland Report, y, también en relación con la protección de la competencia y de los consumidores por autoridades administrativas en Polonia, Sengayen, M., "Poland. Legal system in transition", The Globalization of Class Actions, pp. 30-32.

11 Filatova, Russia Report.
} 
potestades que tienen atribuidas obtenga una mayor aceptación pública, en general y especialmente de los sectores afectados.

En algunos ordenamientos, esta modalidad de organización administrativa carece de implantación ${ }^{12}$ o la tiene muy limitada ${ }^{13}$. En el Derecho argentino se da el fenómeno de órganos administrativos con funciones cuasijurisdiccionales, cuya constitucionalidad ha sido reconocida por la Corte Suprema si cumplen condiciones similares a las de las autoridades administrativas independientes $^{14}$.

En otros ordenamientos las autoridades administrativas independientes tienen amplia implantación y, por lo general, tienen atribuidas las potestades aplicativas del Derecho que protege, en los ámbitos materiales mencionados en el apartado II.1, los intereses supraindividuales, o participan en el ejercicio de esas potestades. En este sentido, algunos informes destacan que tiene esa calidad la autoridad de defensa de la competencia ${ }^{15}$, o la encargada de la defensa de la competencia y de los consumidores ${ }^{16}$. Este modelo organizativo se extiende a gran variedad de sectores en Francia ${ }^{17}$, Italia ${ }^{18}$ y España ${ }^{19}$.

También es relevante que, en los trabajos sobre una Ley Tipo de Defensa de la Competencia, aunque se reconoce que la determinación del organismo apropiado para la defensa de la competencia es cuestión que debe ser decidida por cada país: "La presente ley tipo se ha formulado en el supuesto de que la solución administrativa más eficiente probablemente sería un organismo público cuasi autónomo, con amplias facultades judiciales y administrativas para realizar investigaciones, adoptar decisiones, aplicar sanciones, etc., sin perjuicio de

12 Filatova, Russia Report.

13 Parada CaICedo, Informe Colombia y, también, UNCTAD Guidebook on Competition Systems, United Nations, New York and Geneva, 2007, disponible en http://www.unctad.org/templates/Page. asp?intltemID=4150\&lang=1, p. 39.

14 Merol, Informe Argentina.

15 Honma, Japan Report (the Japanese Fair Trade Commission).

${ }^{16}$ KULSKI, Poland Report (the President of UOKiK). Sobre esta autoridad también, UNCTAD Guidebook, p. 111, y Sengayen, "Poland", The Globalization of Class Actions, pp. 30-32.

17 AmRAnI MeKk (Rolin), Rapport France. Un detallado análisis puede verse en el Rapport d'information fait au nom du comité d'évaluation et de contrôle des politiques publiques sur les autorités administratives indépendantes. Enregistré à la Présidence de l'Assemblée nationale le 28 octobre 2010. № 2925. Assemblée Nationale. Constitution du 4 Octobre 1958. Treizième Législature.

18 Lupol, Italy Report.

19 En España tenemos, por mencionar algunos ejemplos sólo a título ilustrativo, la Comisión Nacional del Mercado de Valores, la Comisión Nacional de las Telecomunicaciones, la Comisión Nacional de la Energía, el Consejo de Seguridad Nuclear, la Comisión Nacional de la Competencia, la Agencia Estatal de Protección de Datos. 
la posibilidad de recurrir a un organismo judicial superior" ${ }^{\prime 20}$. Y, en efecto, esa opción organizativa es la seguida en buena parte de ordenamientos ${ }^{21}$.

\section{3. ¿Qué efectos jurídicos pueden producir las potestades de actuación del Derecho atribuidas a las Administraciones públicas?}

La respuesta a esta cuestión determina el alcance de la protección que pueden obtener, mediante la actuación de las Administraciones públicas, quienes participan en la titularidad de los intereses supraindividuales tutelados por el Derecho aplicado. Los efectos son diferentes de un ordenamiento a otro e, incluso, de una a otra materia dentro del mismo ordenamiento. No obstante, puede constatarse que algunos efectos se hallan establecidos de manera muy generalizada, respecto de otros la previsión está más diversificada, mientras que algunos, en fin, raramente pueden ser producidos por la actuación de la Administración pública.

A) Potestades de autorización, de prohibición y de imposición de sanciones de naturaleza patrimonial, principalmente pecuniarias

Es bastante general que las Administraciones públicas, a veces junto a potestades de reglamentación de rango infralegal, estén habilitadas para producir actos administrativos concretos de autorización o licencia, así como de prohibición de conductas y de actividades. Junto a esto tienen habilitación para imponer sanciones dinerarias -tal vez, genéricamente de naturaleza patrimonial- bien a causa de la infracción de normas abstractas de prohibición, bien por falta de obtención de preceptivas autorizaciones o licencias, bien por la infracción de los términos de esas autorizaciones o de actos concretos de prohibición. ${ }^{22}$

20 United Nations Conference on Trade and Development, Model Law on Competition. Substantive Possible Elements for a Competition Law, Commentaries and Alternative Approaches in Existing Legislation, United Nations, New York and Geneva, 2010, p. 66.

${ }^{21}$ Véase en UNCTAD Guidebook, entre otros paises, respecto de Bélgica (pp. 23-24), Brasil (p. 33), Chile (p. 37), México (pp. 81-82), Holanda (pp. 91-92) y Portugal (pp. 115-116).

22 Honma, Japan Report, Amrani Mekki (Rolin), Rapport France; Filatova, Russia Report; Parada CaiceDO, Informe Colombia; Lupol, Italy Report, Kulskı, Poland Report. En Derecho español, la atribución a autoridades administrativas de potestades de autorización o licencia de actividades, así como de prohibición de las mismas, acompañadas de potestades de imposición de sanciones, está prevista en una amplísima serie de materias: defensa de la competencia, régimen de la publicidad en determinadas materias, telecomunicaciones, protección de intereses generales de consumidores y usuarios, actividades relacionadas con la sanidad y con la producción y comercialización de medicamentos, explotación de la energía nuclear, actividades que puedan afectar al ambiente, mercado de valores, creación y funcionamiento de entidades de crédito, de instituciones de inversión colectiva, de entidades aseguradoras, etc. En los trabajos de la UNCTAD sobre una Ley Tipo de Defensa de la Competencia, se deja a cada ordenamiento nacional la regulación de si la entidad administrativa con potestades de prohibición o de autorización de actividades relacionadas con la libre competencia, debe poder también imponer multas por incumplimiento de la ley o de las resoluciones aplicativas (UNCTAD, Model Law on Competition, pp. 7-8, 72). 
Los resultados de protección de los interesados se producen, en definitiva, a condición de que la fuerza disuasoria ligada a las sanciones previstas y al acto de su efectiva imposición induzcan al cumplimiento, tanto de las normas abstractas, cuanto de las órdenes concretas. Ese cumplimiento comporta que puedan disfrutarse los intereses tutelados.

B) Potestades de restitución al estado anterior a la comisión de una infracción

Cometida una infracción, y, por tanto, lesionados intereses protegidos por las normas, surge una nueva necesidad de protección: restablecer el cumplimiento de la norma, eliminando los resultados producidos por su incumplimiento.

Es conveniente distinguir dos modalidades de esta restitución al estado anterior.

Por un lado, la eliminación de resultados puede consistir en restablecer un estado material de cosas anterior a la infracción. La Administración podría imponer al responsable este restablecimiento y, en caso de incumplimiento, realizar ella misma la restauración a costa del patrimonio del responsable. Potestades administrativas que pueden producir esta clase de efecto las encontramos claramente previstas en algunos ordenamientos ${ }^{23}$.

Por otro lado, los resultados de una infracción han podido consistir en la realización de actos jurídicos, en la celebración de contratos con determinadas cláusulas. La cuestión es si las Administraciones públicas están habilitadas para declarar la invalidez de esos actos o contratos o de las partes de los mismos

23 Honma, Japan Report, Filatova, Russia Report. En Derecho español, en materia de defensa de la competencia, puede ordenarse por la autoridad competente la remoción de los efectos provocados por una conducta restrictiva de la competencia, con multas coercitivas hasta el cumplimiento de ese deber; en caso de infracciones en materia de defensa de consumidores y usuarios, la autoridad competente podrá exigir al infractor la reposición de la situación alterada por la infracción a su estado original. La reparación del daño causado y multas coercitivas o ejecución subsidiaria, a costa del patrimonio del responsable, están previstas en materia medioambiental. Sobre las restricciones a las potestades con esta eficacia en Derecho francés, Amrani Mekk (Rolin), Rapport France; Frier, P. L., Petit, J., Précis de droit administratif, Montchrestien, París, 2010, pp. 333-39.

Por otra parte, la Directiva 2004/35/CE del Parlamento Europeo y del Consejo de 21 de abril de 2004 sobre responsabilidad medioambiental en relación con la prevención y reparación de daños medioambientales, establece que la autoridad competente -puede ser una autoridad administrativa- tenga ciertas atribuciones respecto de la "acción preventiva" (art. 5) y respecto de la "acción reparadora" (art. 6) que le permitan imponer el fin de la actividad dañosa y el restablecimiento del estado libre de contaminación. Los costes deben ser asumidos, salvo algunas justas excepciones establecidas en la Directiva, por el operador. A tal efecto, la autoridad competente recuperará del operador responsable los costes de las medidas adoptadas en virtud de la Directiva: HinteregGer, M., (Ed.), Environmental Liability and Ecological Damage in European Law, Cambridge University Press, 2008, pp. 438-439. En la misma línea se encuadra la medida prevista en el capítulo XI, II, iv del borrador de la Ley Tipo de Defensa de la Competencia (capítulo XI, II, V) (UNCTAD, Model Law on Competition, p. 72). 
contrarias a las normas. La respuesta casi general es negativa: tal declaración sólo puede pedirse y obtenerse de los tribunales de justicia ${ }^{24}$.

No obstante, todavía hay potestades administrativas que pueden producir indirectamente esa corrección o un resultado próximo a la misma ${ }^{25}$. Así, p. ej., potestades de recomendación sobre el carácter abusivo de cláusulas contractuales que, aún no siendo declaraciones vinculantes sobre la validez de las mismas, son respetadas de hecho por los tribunales al resolver los litigios en que esas cláusulas deben ser consideradas; ${ }^{26}$ potestades de imposición a los responsables de los actos o contratos contrarios a la ley de la orden de realizar ellos mismos los actos de revocación, resolución o novación contractual necesarios para el ajuste a la norma, acompañando esa imposición con multas coercitivas hasta el cumplimiento ${ }^{27}$.

C) Potestades de imposición de indemnizaciones dinerarias a favor de los interesados perjudicados

Los ordenamientos coinciden de nuevo, pero en una respuesta negativa: las potestades administrativas de actuación del Derecho que protege intereses supraindividuales, no pueden establecer indemnizaciones a favor de los perjudicados, ni imponer a los responsables el pago de las mismas. Este efecto jurídico está reservado a la potestad propia de los tribunales de justicia ${ }^{28}$.

\section{Efectividad y eficiencia de la actuación por las Administraciones públicas del Derecho que protege intereses supraindividuales}

Las potestades administrativas que acabamos de tratar han de ser también valoradas desde el punto de vista de la efectividad-ejercicio real y producción de resultados prácticos-.

\footnotetext{
${ }^{24}$ Amrani Mekki (Rolin), Rapport France; Filatova, Russia Report; Parada Caicedo, Informe Colombia.

${ }_{25}$ No me refiero a las excepcionales atribuciones de funciones jurisdiccionales a ciertas autoridades administrativas. Así, en Colombia, algunas potestades de la Superintendencia de Industria y Comercio: PARADA CAICEDO, Informe Colombia; también UNCTAD Guidebook, p. 39.

26 Amrani MekKi (Rolin), Rapport France.

27 Es una técnica que se aplica, p. ej., en la legislación española de defensa de la competencia. A la misma se refiere también la medida prevista en el capítulo XI, II, V del borrador de la Ley Tipo de Defensa de la Competencia (capítulo XI, II, v) (UNCTAD, Model Law on Competition, p. 72).

${ }^{28}$ En este sentido, Amrani Mekki (Rolin), Rapport France, Filatova, Russia Report, Parada Caicedo, Informe Colombia. En Derecho español, p. ej., art. 19 de la Ley de Protección de Datos de Carácter Personal y el art. 48 de la Ley General para la Defensa de los Consumidores y Usuarios. En relación con las modalidades de protección jurídica de los consumidores, CAFAGGI, MICKLITZ, "Administrative and Judicial Collective Enforcement", p. 24. Y para la falta del poder de imponer el pago de indemnizaciones por las autoridades administrativas de defensa de la competencia en el ámbito europeo, Möllers, Heinemann, Eds., The Enforcement of Competition Law, pp. 397-421.
} 
A) ¿Por qué es -o se considera que es-más efectiva la actuación del Derecho por las Administraciones públicas que por los tribunales de justicia?

a) Las principales ventajas

Hay varias razones a favor de la efectividad de la actuación administrativa ${ }^{29}$. La protección de los intereses supraindividuales se beneficia de una estructura administrativa organizada para ese fin y de la profesionalidad de las Administraciones responsables. Lo anterior suele incluir la existencia de servicios de inspección para el descubrimiento de conductas infractoras, facilidad para la reunión de pruebas y de documentación. Por lo demás, las Administraciones públicas incorporan personal con capacidad para realizar no sólo apreciaciones jurídicas, sino también apreciaciones científico-técnicas de otra naturaleza, frecuentemente necesarias para la aplicación de las normas jurídicas relativas a las materias mencionadas en el apartado II. $1^{30}$. Por otra parte, el procedimiento es ágil, casi expeditivo, y, muy frecuentemente, las Administraciones están investidas de poderes coercitivos para vencer determinadas resistencias. Esto es particularmente idóneo para una protección preventiva ${ }^{31}$.

Que la Administración deba actuar de oficio es, por sí mismo, muy beneficioso para los interesados ${ }^{32}$. Pero, además, si estos consideran que les conviene instar la actuación de la Administración ${ }^{33}$, el sistema también tiene ventajas para ellos $^{34}$, porque no precisan -al menos por norma jurídica- contratar asistencia técnico-jurídica o de otra naturaleza, ni impulsar la actuación administrativa después de iniciada.

Los trabajos sobre el borrador de Ley Tipo de Defensa de la Competencia revelan, también, la importancia decisiva de los aspectos que acabamos de comentar en orden a la más idónea ordenación de las funciones y facultades del órgano encargado de la defensa de la competencia ${ }^{35}$.

\footnotetext{
29 Amrani MekKi (Rolin), Rapport France; LuPOI, Italy Report. Crítica respecto de esta efectividad, FILATOVA, Russia Report.

30 Kulski, Poland Report, Filatova, Russia Report, Parada Caicedo, Informe Colombia.

31 Honma, Japan Report; Lupol, Italy Report.

32 Amrani Mekki (Rolin), Rapport France.

33 Depende de cada ordenamiento que los interesados tenga facultad de instar la iniciación de un procedimiento administrativo y de participar en él, así como quién ha de ser considerado interesado. El régimen en principio diseñado por la Directiva 2004/35/CE del Parlamento Europeo y del Consejo de 21 de abril de 2004 sobre responsabilidad medioambiental en relación con la prevención y reparación de daños medioambientales es revelador de posibles restricciones en esta materia. Acerca de las facultades de los interesados en los Derechos de los Estados miembros y respecto de su eficacia para provocar el ejercicio de las potestades de la Administración pública, HiNTEREGGER, (Ed.), Environmental Liability, pp. 436-438, 622-623.

34 Honma, Japan Report; Fllatova, Russia Report.

35 UNCTAD, Model Law on Competition, pp. 68-69.
} 
b) Las matizaciones de las ventajas

No obstante, esos beneficios pueden sufrir restricciones.

Una primera dificultad puede provenir de la falta de una posibilidad de reaccionar de modo efectivo contra la inactividad de las Administraciones públicas. La importancia de esta dificultad depende del régimen de los diversos ordenamientos estatales sobre el control jurisdiccional de la inactividad de las Administraciones públicas. Algunos informes expresan opiniones positivas sobre la efectividad de ese control ${ }^{36}$, mientras que otros, con datos más precisos, revelan una tendencia restrictiva ${ }^{37}$.

En segundo lugar, el carácter expeditivo de la actuación administrativa y la inmediatez de la protección jurídica que produce, experimentan una moderación por la incorporación de garantías de defensa en el procedimiento, en especial para la imposición de sanciones ${ }^{38}$.

Por fin, aunque no ha contado con suficiente confirmación en los informes nacionales ${ }^{39}$, si bien según el régimen normativo el procedimiento administrativo es menos costoso para el interesado, porque no requiere su permanente impulso, ni que asuma el coste de la colaboración de técnicos, estas ventajas pueden perderse por una defectuosa aplicación práctica de aquel régimen.

B) Los contrapesos a la efectividad derivados del régimen de control de la actuación de las Administraciones públicas por los tribunales de justicia

El control jurisdiccional de la actividad de las Administraciones públicas -uno de los postulados del Estado de Derecho- puede incidir sobre la efectividad de la protección de los intereses supraindividuales que hubiera sido concedida, en principio, por una resolución administrativa. Según se regule aquel control -principalmente en los dos aspectos que veremos a continuación- la protección administrativa tendrá mayores opciones de permanecer preservada o, por el contrario, quedará más expuesta a ser reducida o eliminada, incluso mientras se desarrolla el proceso judicial.

a) Suspensión de los efectos de las resoluciones administrativas impugnadas y otras modalidades de tutela judicial provisional

36 Filatova, Russia Report; Honma, Japan Report, se refiere a una modificación de la Ley procesal administrativa que habría mejorado el control de la inactividad.

37 Amrani MekKi (Rolin), Rapport France; Parada CAicedo, Informe Colombia. La limitación del control jurisdiccional de la inactividad administrativa radica, principalmente, en la característica de la precisión con la que debe estar establecido -en una norma, en un convenio, en una preexistente resolución administrativa (p. ej. art. 29 de la española Ley Procesal Administrativa)- el correspondiente deber de actuar de la Administración.

38 Amrani Mekki (Rolin), Rapport France; Honma, Japan Report.

39 Filatova, Russia Report, expresa dudas sobre la agilidad de la actividad de la Administración si el interesado no la impulsa con apoyo de técnicos en Derecho. 
La impugnación de la resolución administrativa ante los tribunales puede afectar a su eficacia ejecutiva, cuyo carácter inmediato era factor clave de la efectividad de la actuación administrativa del Derecho. Unos ordenamientos son propicios a mantenerla -porque las normas son restrictivas de la suspensión o los tribunales tienden a denegarla en la práctica-, otros son favorables a la suspensión salvo que se acrediten concretas justificaciones a favor del mantenimiento de la ejecución; en fin, la tutela judicial provisional frente a la actividad (o inactividad) administrativa permite que el tribunal adopte medidas distintas a la suspensión y que establecen una protección provisional de intereses diferente a la que resultaba de la resolución administrativa impugnada.

Salvo que predomine la primera solución enunciada ${ }^{40}$, las otras dos contrarrestan la efectividad de la resolución administrativa, por excluir provisionalmente la protección concedida ${ }^{41}$, o por modificar la protección en consideración de otros intereses afectados ${ }^{42}$.

b) Amplitud de la revisión jurisdiccional de la previa actividad administrativa, en especial en el caso de autoridades administrativas independientes

El factor de efectividad consistente en que la resolución administrativa ha sido dictada por una autoridad especializada en la materia, con aptitud para apreciar los aspectos no jurídicos del caso y con acceso a una información idónea, puede ser contrarrestado si el control jurisdiccional es muy intenso:

1) Muchas normas reguladoras de las materias del apartado II.1 incluyen conceptos jurídicos indeterminados y habilitaciones de discrecionalidad -frecuentemente en su modalidad técnica- a las autoridades administrativas. En el momento del control jurisdiccional se plantea con fuerza la cuestión de en qué medida los tribunales pueden revisar y sustituir apreciaciones de las autoridades administrativas de carácter no estrictamente jurídico, cuya revisión jurisdiccional es, por tanto, dudosa.

2) Si la resolución administrativa hubiera sido dictada por una autoridad independiente, la problemática mencionada se plantea con más intensidad, porque a las cualidades técnicas de la autoridad administrativa, se añade el estatuto de

40 Honma, Japan Report, aunque se han producido reformas que favorecen la suspension; FILATova, Russia Report; PARADA CAICEDO, Informe Colombia.

${ }^{41}$ Así la simple suspensión de la ejecución del acto. P. ej., aunque no especifica los requisitos, ni la frecuencia de aplicación, KULSkı, Poland Report. En Derecho alemán, el Widerspruchsverfahren (impugnación del acto en vía administrativa) tiene, por lo general, efecto suspensivo: Hufen, F., Verwaltungsprozessrecht, C.H. Beck, 3 Auf., München, 1998, pp.118-119.

${ }^{42}$ Un régimen de tutela judicial provisional más completo que la medida de suspensión está previsto en Derecho alemán - Hufen, Verwaltungsprozessrecht, pp. 531 ss.-, en Derecho italiano -arts. 55, 56 y 61 del Codice del Processo Amministrativo de 2 julio 2010-, en Derecho francés -Frier, Petit, Précis de droit administratif, pp. 463-468- y en Derecho español -Ortells Ramos, M., "La tutela cautelar en el nuevo proceso contencioso-administrativo", en La nueva Ley de la Jurisdicción contenciosoadministrativa, Diputación de Valencia, Valencia, 1999, pp. 75-102-. 
independencia e imparcialidad, todo lo cual podría justificar una contención del control jurisdiccional, por la ley o por práctica judicial autorrestrictiva.

Algunos informes nacionales se limitan a referirse a la previsión de un control jurisdiccional ${ }^{43}$, mientras que en otros se pone énfasis en la plenitud del control jurisdiccional aunque hayan resuelto autoridades administrativas independientes $^{44}$. Sin embargo, en la importante materia de defensa de la competencia, los trabajos sobre el borrador de la Ley Tipo de Defensa de la Competencia revelan una notable diversidad del alcance del control jurisdiccional de las resoluciones dictadas por autoridades independientes ${ }^{45}$.

C) Actuación del Derecho por las Administraciones públicas, gasto público e incidencia en el plano macroeconómico

La valoración de la eficiencia de esta modalidad de actuación del Derecho debe hacerse en un doble plano:

1) El de la proporción entre la financiación pública requerida para la dotación de los servicios y el nivel de resultados obtenidos.

2) En un plano de más complejo análisis, habría que inquirir sobre la relación entre grados de intensidad de la actuación del Derecho por las Administraciones públicas (de la regulación, de la intervención) y el desarrollo y resultados de la economía en el ámbito de vigencia del sistema jurídico correspondiente.

Los datos que nos han proporcionado los informes nacionales han sido escasos y más que en referencias cuantitativas ${ }^{46}$, han consistido en apreciaciones cualitativas, muy críticas con una intervención administrativa excesivamente intensa ${ }^{47}$, otras matizadamente críticas $^{48}$, otras, en fin, favorables a un grado notable de actuación administrativa ${ }^{49}$.

IV. LA PROTECCIÓN DE INTERESES SUPRAINDIVIDUALES EN EL PROCESO CIVIL Y UN PROCESO CIVIL PARA LA PROTECCIÓN DE INTERESES SUPRAINDIVIDUALES

Junto al escenario descrito en el anterior apartado III, existe la posibilidad o la realidad-incipiente o muy desarrollada- de que pueda pretenderse directamente ante los tribunales la protección de los intereses amparados por el Derecho que rige las materias sintéticamente recordadas en el apartado II.

\footnotetext{
43 Honma, Japan Report; Filatova, Russia Report; Parada Caicedo, Informe Colombia.

44 Merol, Informe Argentina; KULSKI, Poland Report; LuPOI, Italy Report.

45 UNCTAD, Model Law on Competition, p. 75.

46 Filatova, Russia Report, alude a datos orientativos disponibles en The Global Enabling Trade Index y en The Global Competitiveness Index 2010-2011.

47 Filatova, Russia Report.

48 Honma, Japan Report.

49 Amrani MekKI (Rolin), Rapport France.
} 


\section{Una referencia a la protección de los intereses supraindividuales en la ordenación tradicional del proceso civil}

La protección de los intereses supraindividuales en el proceso civil tradicional no era desconocida, pero sí muy limitada.

A) Los poderes de oficio del tribunal para desestimar pretensiones

El poder de desestimar pretensiones porque les falta justificación jurídica tiene un alcance muy amplio y genérico, consistente en un poder de oficio del tribunal para proteger los límites imperativos a la autonomía de la voluntad. Funciona como una especie de potestad de inaplicación, porque aunque el tribunal no pueda declarar la nulidad, sí que debe resolver desconociendo la validez de los actos o contratos infractores de aquellos límites ${ }^{50}$.

Más potente sería la potestad del tribunal si pudiera declarar la nulidad del contrato, sin que hubiera sido pedida en pretensión principal o reconvencional ${ }^{51}$.

Estos poderes tienen escasa efectividad práctica. El tribunal no tiene oportunidad de ejercerlos salvo que los interesados -que deciden su acción procesal estrictamente por su interés privado- sometan un caso que haga posible el ejercicio. Planteado el caso, las limitaciones surgen a causa del carácter predominante de los poderes de las partes en el proceso civil, en cuanto a la aportación del material de hecho $0^{52}$ y a la acotación del poder de decisión del tribunal ${ }^{53}$.

B) La previsión legal de dictamen o de informe de una persona o entidad que tiene atribuida la defensa de los intereses supraindividuales

Es un paso adicional la previsión de que un "portavoz" de los intereses supraindividuales (suele ser el Ministerio Público) pueda exponer sus alegaciones y apreciaciones en el proceso, aunque sin tener estatuto de parte, y, por tanto, sin que su posición sea relevante para determinar la congruencia del pronunciamiento jurisdiccional. A pesar de esta limitación, esta previsión es importante porque fomenta y facilita el ejercicio de los poderes judiciales que pueden ser ejercitados de oficio -construcción del razonamiento de valoración de la prueba,

\footnotetext{
50 MEROI, Informe Argentina.

51 La Sala Primera del Tribunal de Justicia de la Unión Europea, por sentencia de 17 de diciembre de 2009, y en respuesta a cuestión prejudicial planteada por un tribunal español, ha declarado que el art. 4 de la Directiva del Consejo 1985/577/CEE, de 20 de diciembre de 1985, sobre protección de los consumidores en el caso de contratos negociados fuera de los establecimientos comerciales, puede ser interpretado en el sentido de autorizar a los tribunales, en casos de omisión del deber de información del específico derecho de rescisión -lo que afecta al interés público protegido por la Directiva-, a declarar de oficio la nulidad del correspondiente contrato, aunque la misma no hubiera sido alegada por el consumidor demandado en ningún momento del proceso.

52 AmRani MeKKI, Rapport France.

53 En este sentido, AmRani MeKkI, Rapport France. En sentido diferente, para el Derecho italiano, LuPOI, Italy Report. Respuestas matizadamente negativas en Merol, Informe Argentina y también en FiLATOVA, Russia Report.
} 
interpretación y aplicación de normas, integración normativa, concreción de conceptos jurídicos indeterminados-, pero que, de hecho, podrían no ser ejercitados, o no serlo de modo atento a los intereses supraindividuales en juego.

C) Legitimación plural y atribución de legitimación a personas o entidades diferentes a los titulares de la relación jurídica litigiosa

La protección específica y plena de los intereses supraindividuales se producía (y se produce), en el proceso civil tradicional, en dos ámbitos de muy diferente significación.

Por un lado, encontramos los fenómenos litisconsorciales, relacionados con la litigiosidad sobre derechos subjetivos con más de un titular o respecto de actos jurídicos o de contratos que vinculan a más de un titular o producen efectos para una pluralidad de personas.

Por otro lado, están los supuestos -muy limitados en los ordenamientos en los que el Derecho material está informado por el principio de la autonomía de la voluntad- en los que el Derecho material que rige determinadas instituciones (generalmente cuestiones de estado civil) es, en su conjunto, Derecho imperativo, de modo que, para que la esencia de este Derecho no resulte alterada cuando deba ser aplicado por los tribunales, los poderes de las partes y del tribunal son configurados de modo diferente al general en el proceso civil.

La manifestación más radical de un proceso civil no dispositivo consiste en atribuir legitimación activa a un órgano del poder público (el Ministerio Público) que debe actuar de acuerdo con el principio de legalidad. Se aproximan a ese tratamiento las normas que -sin llegar a la atribución mencionada-amplían el círculo de legitimados activos más allá de los titulares de la relación jurídica litigiosa, para que la eventual inactividad de estos no excluya absolutamente un posible pronunciamiento jurisdiccional.

D) El régimen del recurso ante el más alto tribunal en un ordenamiento

La consideración de los intereses públicos -en este caso consistentes en garantizar la igualdad en la aplicación de las normas y la seguridad jurídica- se manifiesta en los criterios de selección de las resoluciones recurribles, atentos, principalmente o entre otros fines, a que el recurso haga posible la fijación de una doctrina jurisprudencial sobre el significado de las normas y que oriente hacia una unificación del entendimiento de ese significado; también en las reglas sobre admisión de motivos del recurso y sobre las cargas y deberes de las partes en el procedimiento del recurso; en fin, en el establecimiento de normas o, por lo menos, de prácticas que reconozcan a las sentencias dictadas en el recurso "supremo" un valor adicional al de la resolución del concreto caso litigioso ${ }^{54}$.

54 Sirva de ejemplo esta disposición de la Ley española de Contrato de Seguro: "Declarada por el Tribunal Supremo la nulidad de alguna de las cláusulas de las condiciones generales de un contrato, 
2. Las cuestiones nucleares para la renovación de la tutela de los intereses supraindividuales mediante el proceso civil: legitimación activa, clases de tutela judicial, extensión subjetiva y valor de sus efectos

Los cambios más importantes para que el proceso civil sirva a la tutela de intereses supraindividuales son los relativos a las cuestiones nucleares de la configuración de la tutela judicial, a saber:

1) ¿Quién tiene la legitimación activa?

2) ¿Respecto de qué materias jurídicas y de qué clases de derechos o de intereses jurídicos?

3) ¿Qué clase de tutela judicial puede obtener?

4) ¿Cuál es el alcance subjetivo de los efectos de esa tutela y del valor de cosa juzgada?

Se ha obtenido una compleja constelación de respuestas, que no será fácil presentar de un modo suficientemente claro y completo, tal vez porque estas cualidades faltan en la propia realidad considerada. He elegido un criterio de sistematización que destaca una información interesante: unos ordenamientos han optado por un régimen general, que presta mayor atención a los aspectos procesales; otros han incorporado la regulación como un complemento del régimen jurídico de sectores del Derecho material con diferente grado de especialidad.

A) Ordenamientos que han establecido un régimen general

a) Brasil

La Lei de Ação Civil Pública configuró una acción para "proteger el medio ambiente, al consumidor y a los derechos de valor artístico, estético, turístico y de paisaje". El ámbito de aplicación de las acciones colectivas se extendió, por intervenciones legislativas posteriores, a la protección de toda clase de derechos difusos o colectivos. La Lei $n^{\circ}$ 8.078, de 11 de setembro de 1990, dispõe sobre a proteção do consumidor e dá outras providências (en adelante, Código do Consumidor), reguló el litigio de las acciones colectivas por daños individuales y determinó que sus normas sobre el procedimiento colectivo fueran de aplicación en todos los litigios para la protección de derechos de grupo ${ }^{55}$.

La legitimación activa está atribuida, además de a entidades públicas (apartado V.2,A), a asociaciones privadas (organizaciones no gubernamentales). Las personas, aunque estén afectadas como componentes del grupo, no están indi-

la Administración pública competente obligará a los aseguradores a modificar las cláusulas idénticas contenidas en sus pólizas".

55 GIDI, A., Las acciones colectivas y la tutela de los derechos difusos, colectivos e individuales en Brasil. Un modelo para países de Derecho civil, Universidad Autónoma Nacional de México, México D. F., 2004, pp. 19-23; Pellegrini Grinover, A., "The defense of transindividual interests: Brazil and Iberoamerica", The Globalization of Class Actions, apartados 5, 7, 12 y 14. 
vidualmente legitimadas para pretender la tutela de los intereses del grupo ${ }^{56}$. Las asociaciones deben cumplir algunos requisitos legales, pero no están sometidas a autorizaciones o certificaciones administrativas ${ }^{57}$.

Pueden obtener tutela judicial declarativa de la ilicitud de conductas, de condena a cesar en su realización, a restaurar el estado de cosas que alteraron e incluso al pago de una cantidad para indemnizar el daño global causado a la colectividad ${ }^{58}$. Pero la tutela de los derechos e intereses individuales dependientes del objeto litigioso colectivo ha de ser pretendida por sus titulares individuales ${ }^{59}$.

El proceso sobre acciones de protección de intereses difusos y colectivos produce efecto de cosa juzgada con alcance subjetivo según la regla general en cuanto a su objeto propio. En lo que se refiere a las acciones para la protección de derechos individuales -cuyo fundamento depende del pronunciamiento sobre acciones colectivas stricto sensu-, si la demanda sobre las últimas es desestimada, no hay cosa juzgada para la acción individual. Pero si es estimada, el legitimado para la acción individual puede aprovechar la parte del pronunciamiento sobre la acción colectiva que le es favorable para fundar su pretensión individual ${ }^{60}$.

b) Colombia

Una ley de 1998 desarrolla el art. 88 de la Constitución Política de Colombia en relación con el ejercicio de las acciones populares y de grupo. Las acciones populares protegen los derechos e intereses colectivos, relacionados con el patrimonio, el espacio, la seguridad y la salubridad pública, la moral administrativa, el ambiente, la libre competencia económica y otras de similar naturaleza.

La legitimación activa para las acciones populares corresponde a cualquier persona natural, sin que deba acreditar un interés legítimo. También a asociaciones, fundaciones, gremios, y otras personas jurídicas, sin otros requisitos que los generales para la constitución ordinaria de esos entes.

Pueden pretender cualquier tipo de medida para el restablecimiento o la protección de los derechos o intereses colectivos lesionados o puestos en peligro.

56 GidI, Las acciones colectivas, pp. 72-73; Pellegrini Grinover, "Brazil and Iberoamerica", The Globalization of Class Actions, apartado 7.

57 GIDI, Las acciones colectivas, pp. 74, 81, 84-85.

${ }^{58} \mathrm{GIDI}$, Las acciones colectivas, pp. 57-59.

${ }^{59}$ GIDI, Las acciones colectivas, pp. 61-63; Pellegrini Grinover, "Brazil and Iberoamerica", The Globalization of Class Actions, apartado 8.

60 Pellegrini Grinover, "Brazil and Iberoamerica", The Globalization of Class Actions, apartados 12-14; GIDI, Las acciones colectivas, pp. 100-102. 
La ley también regula las acciones por daños causados a un número plural de personas. Sin perjuicio de las demandas individuales, se regula una acción de grupo, que se ejercita mediante demanda presentada por un abogado, con poder de uno o más miembros de un grupo integrado, como mínimo, por veinte personas. Se puede pretender condena a indemnización y la cosa juzgada afectará a cualquier persona integrante del grupo, salvo que manifieste su intención de separarse de la acción ${ }^{61}$.

c) Argentina

La llamada acción de amparo colectivo está prevista por la Constitución Nacional, desde 1994, como medio de tutela "contra cualquier forma de discriminación y en lo relativo a los derechos que protegen al ambiente, a la competencia, al usuario y al consumidor, así como a los derechos de incidencia colectiva en general". Es dudoso si la cláusula general incluye los "intereses plurales homogéneos". La legislación así lo ha entendido en materia de protección a consumidores, pero no lo ha aclarado en general. La jurisprudencia de la Corte Suprema (caso Halabi) también ha respondido afirmativamente para los derechos de naturaleza no patrimonial.

Legitimados activamente lo están, además de un ente público (el defensor del pueblo), el afectado y las asociaciones cuyos fines se relacionen con la protección de aquellos intereses, registradas de acuerdo con una ley, que las regulará específicamente. Aunque esta ley no ha sido dictada, la jurisprudencia ha reconocido la legitimación atendiendo a los requisitos generales establecidos en la Constitución. ${ }^{62}$ También jurisprudencialmente ha sido superada la falta de regulación de la acción ejercitada por un "grupo de afectados" 63.

Para la clase de tutela que puede obtenerse y el alcance de los efectos de la sentencia y de su valor de cosa juzgada, me remito a los apartados IV.2.B y C, c.

d) Trabajos para un Código Modelo de Procesos Colectivos para Iberoamérica

En la redacción provisional aprobada en Caracas, en 2004, la acción colectiva tiene por finalidad la protección tanto de intereses o derechos difusos, como de intereses o derechos individuales homogéneos -conjunto de derechos subjetivos individuales, provenientes de origen común-, sin acotarlos a los que surgen en áreas jurídicas específicas (art. 1).

La legitimación activa se atribuye, además de a algunas entidades públicas, a las personas pertenecientes al grupo, y a asociaciones entre cuyos fines

61 Parada CAICEDO, Informe Colombia.

62 Merol, Informe Argentina, con cita de Lorenzeti.

63 Merol, Informe Argentina. 
se halle la defensa de los intereses litigiosos (art. 3). La representatividad del legitimado activo, más allá del cumplimiento formal de los requisitos legales, es valorada por el juez.

Pueden obtenerse todas las clases de tutela, incluidas condenas al pago de indemnizaciones del daño colectivo (arts. 4 y 8). La condena a indemnización de daños y perjuicios individuales puede obtenerse con el carácter de condena genérica; las pretensiones de condena individualizadas se presentarán, como regla general, por sus titulares en procedimientos incidentales del que dio lugar a la condena genérica (arts. 20-24).

Los efectos de la sentencia colectiva alcanzan a todos los afectados que participan en la titularidad de los intereses difusos o colectivos litigiosos, pero los titulares de derechos o intereses individuales homogéneos pueden pretender su tutela en demanda individual (no les afecta, pues, la cosa juzgada). Si la demanda colectiva es desestimada, no hay cosa juzgada respecto de las pretensiones individualizadas de indemnización (art. 33).

e) Referencias a otros ordenamientos

En Japón tiene un ámbito muy general la litigación mediante designación de una parte, que ejercita la acción por un amplio número de titulares que comparten un interés común. ${ }^{64}$ La parte representante ha de ser designada por escrito $^{65}$. Los efectos de la sentencia se extienden a quienes hubieran hecho la designación. Se puede pretender cualquier clase de tutela, por lo que esta técnica es útil para completar la tutela colectiva de consumidores, limitada a las pretensiones de cesación ${ }^{66}$.

En Rusia, la legislación federal sobre organizaciones autónomas (self-regulated organizations) les atribuye legitimación activa respecto de los intereses de sus miembros, en cuanto colectivo, para pretender condena a cesación de conductas que los violen. La condena a indemnización está reservada a cada individuo, pero éste se beneficia de la sentencia obtenida por la organización en la parte que es común con el fundamento de su pretensión ${ }^{67}$. Por otra parte, en un ámbito material no general, pero sí amplio ${ }^{68}$, una reforma de 2009 ha

\footnotetext{
${ }^{64}$ Honma, Japan Report.

65 Esto complica la aplicación de esta técnica si el número de posibles interesados es muy amplio, aunque la forma de este requisito fue reformada para facilitar el cumplimiento (simple escrito de adhesión a la designación ya efectuada): SugaWARA, I., "The current situation of class action in Japan", The Globalization of Class Actions, pp. 5-6, 9-11.

${ }^{66}$ Honma, Japan Report.

67 Filatova, Russia Report.

${ }^{68}$ Filatova, Russia Report: "(R)esolution of disputes arising from corporate relationships, claims related to the activities of the securities market actors, and other claims of economic nature meeting the established requirements for group litigation".
} 
regulado una acción interpuesta por un demandante por un grupo de no menos de cinco personas afectadas en sus derechos comunes u homogéneos. Puede pretender cualquier modalidad de tutela y la cosa juzgada se extiende a los miembros del grupo que han expresado adhesión.

En Francia, la jurisprudencia, más allá de específicas previsiones legales, ha reconocido a las asociaciones legalmente constituidas legitimación activa para la defensa de los intereses colectivos incluidos en su objeto social ${ }^{69}$. Pero esta legitimación no alcanza a la defensa de intereses públicos, ni a la de intereses privados ${ }^{70}$.

B) Protección de los derechos e intereses de los consumidores

Si se atiende a la amplitud de las materias jurídicas respecto de las cuales se han establecido normas de legitimación activa adecuadas para la tutela de intereses supraindividuales, las dirigidas a la protección de los consumidores ${ }^{71}$ ocupan el segundo lugar, después de la opción de técnica legislativa por una regulación de ámbito material general.

a) Legitimación activa y modalidades de tutela de los intereses colectivos y difusos de los consumidores

La protección judicial de los intereses comunes, compartidos, no individualizados, de los consumidores, presenta diversas variantes en el régimen de la legitimación activa.

Algunos ordenamientos limitan las normas especiales de legitimación activa a áreas jurídicas específicas ${ }^{72}$, no obstante predomina la opción de establecer esas normas con referencia a cualquier violación de los intereses

\footnotetext{
${ }^{69}$ Amrani MeKkI, Rapport France, con cita de Civ. 1, 18 septembre 2008, JCP 2009, I, 142, № 5.

70 Magnier, V., "Class Actions, Group Litigation and Other Forms of collective litigation. France", The Globalization of Class Actions, pp. 5-9; CADIET, L., "Future Prospects for Collective Redress in EuropeTowards a System of Class Actions? The State of Play in France", en ZZPInt 13 (2008), pp. 5-6.

${ }^{71}$ Esa calidad tiende a ampliarse, p. ej., a los inversores, para los que se establecen normas de tutela judicial especiales similares a las previstas para los consumidores. Así, BAEtGE, D., "Class Actions, Group Litigation and other Forms of Collective Litigation. Germany", The Globalization of Class Actions, p. 5; MAGNier, "France", The Globalization of Class Actions, pp. 8-9.

${ }^{72}$ Véanse, dentro de este apartado IV.2, el sub-apartado C. El grado de especialidad puede ser mayor que el que tendremos oportunidad de exponer. P. ej., en Derecho español, las previsiones de legitimación activa de las asociaciones de consumidores -y de ciertas entidades públicas- para pretender condenas a cesación de conductas infractoras de la Ley de Crédito al Consumo, de la Ley General de Publicidad y de la regulación del comercio electrónico.
} 
de los consumidores ${ }^{73}$, sin perjuicio de regularla también en algunas áreas específicas $^{74}$.

Además de la legitimación de entidades públicas (apartado V.2.A), hay dos modelos de atribución de legitimación: asociaciones u otras entidades creadas según las normas generales y cuyo objeto social incluya la defensa de los intereses de los consumidores ${ }^{75}$, y asociaciones especiales $y$, a veces, sujetas a homologación o acreditación por la Administración pública ${ }^{76}$.

La tutela judicial se ciñe a las declaraciones de licitud de conductas y a la condena a cesar en las mismas; no incluye pretensiones de condena a indemnizar daños de cada consumidor ${ }^{77}$. No obstante, en algunos ordenamientos los consumidores pueden beneficiarse de las sentencias pronunciadas sobre tutelas colectivas, invocando las declaraciones de ilicitud para integrar el fundamento de sus acciones singulares ${ }^{78}$.

b) Legitimación activa para la defensa de los derechos e intereses individuales de los consumidores lesionados por una causa común

La lesión de derechos e intereses de consumidores singulares se produce en un amplio número de casos, de ahí que algunos ordenamientos, junto a la legi-

73 Mairal, "Argentina", The Globalization of Class Actions, p. 6; Merol, Informe Argentina; Parada Caicedo, Informe Colombia; Baetge, "Germany", The Globalization of Class Actions, p. 5; Orfanidis, Griechenland Bericht; Kulskı, Poland Report; FILAtova, Russia Report; Lupol, Italy Report. En España, las asociaciones de consumidores y usuarios legalmente constituidas tienen legitimación activa para la defensa de los intereses en materia de consumo que tengan la calidad de intereses generales de consumidores y usuarios y esta legitimación les corresponde porque la defensa de esos intereses es uno de sus fines estatutarios (Gutierrez de Cabiedes, P., en Comentarios a la Ley de Enjuiciamiento Civil, (coord. Cordón, Armenta, Muerza y Tapia), I, Aranzadi, 2001, pp. 155-157, quien considera más adecuada la expresión de intereses colectivos o difusos).

${ }^{74}$ Véanse, dentro de este apartado IV.2, el sub-apartado C. Un estudio de detalle podría detectar diferencias entre la regulación más general y las especiales, o una estricta concurrencia.

75 Parada Caicedo, Informe Colombia; Kulski, Poland Report, Sengayen, "Poland", The Globalization of Class Actions, p. 26; Filatova, Russia Report.

${ }_{76} \mathrm{MeROI}$, Informe Argentina; BAETGE, "Germany", The Globalization of Class Actions, pp. 4-6, 16; OrFANIDIS, Griechenland Bericht; LuPOI, Italy Report. También en España, donde el art. 11 de Ley Procesal Civil requiere la específica constitución como asociación de consumidores o la calidad adicional de ser de las más representativas.

77 En Argentina una reforma de 2008 de la Ley de Defensa del Consumidor ha posibilitado que las asociaciones puedan pretender condenas a indemnización (MEROI, Informe Argentina), pero en este caso necesitan alguna forma de consentimiento de los titulares de los respectivos derechos (arts. 53 y 54 de la Ley citada). Para Francia, véase el anterior apartado IV.2.A.e. También, OrfanidIs, Griechenland Bericht; Baetge, "Germany", The Globalization of Class Actions, p. 22); Sengayen, "Poland", The Globalization of Class Actions, p. 48; FILATOVA, Russia Report. Para el Derecho italiano, resulta significativo lo dispuesto por el art. 140.1 del Codice del Consumo, que no incluye la condena a indemnizaciones.

${ }^{78}$ En este sentido, Kulskı, Poland Report, Filatova, Russia Report; Baetge, "Germany", The Globalization of Class Actions, p. 14. Por el contrario el problema no está satisfactoriamente resuelto en Francia, AmRANI MekKI, Rapport France; tampoco en Japón: Honma, Japan Report. 
timación de cada consumidor, establecen un régimen especial de legitimación activa para formular el conjunto de las pretensiones de indemnización. Me limitaré a sintetizar los rasgos más relevantes de un panorama muy diversificado.

En Argentina, las mismas asociaciones de consumidores legitimadas para defender intereses colectivos y difusos, pueden pedir tutela de derechos e intereses individuales si acreditan el mandato conferido -con formalidades simplificadas- por su titular, aunque una reforma de esta ley conduce a concluir que lo relevante es la falta de una expresa declaración de autoexclusión del consumidor debidamente informado de la pendencia del proceso cuya sentencia le puede afectar ${ }^{79}$.

En Colombia, la Ley 472/1998 regula (art. 46) las acciones interpuestas por al menos veinte personas, que hayan sufrido perjuicios individuales por la misma causa, y destinadas a la indemnización de los perjuicios. El grupo actuará mediante un abogado designado o, caso de ser varios, por el abogado coordinador del comité que se constituye. El actor o actores iniciales representan a las demás personas que hayan sido afectadas individualmente, sin necesidad de que estos ejerzan por separado su propia acción, ni de que otorguen poder (art. 48). Pero estas personas deberán ser informadas de la pendencia del proceso por un medio efectivo (art. 53), y podrán expresar positivamente su adhesión -aportando datos relevantes para el proceso- o manifestar expresamente su autoexclusión (art. 56), con la consecuencia de no ser afectadas por la sentencia.

En Francia, el Code de la Consommation dispone que las asociaciones de consumidores registradas y de ámbito nacional, con la previa autorización escrita de al menos dos consumidores, perjudicados por una causa común y atribuible al mismo profesional, pueden pretender condena a la indemnización de daños a favor de aquellos. La manifestación expresa, positiva y formalizada de voluntad no puede ser requerida por determinados medios masivos de información ${ }^{80}$.

Para el Derecho alemán, "In 2002, a provision was introduced into the Law on Legal Advice, according to which individual consumers may assign their claims, including claims for monetary relief, to a consumer association. The association may then file suit on their behalf "if this is necessary in the interest of consumer protection". The provision is an exception to the rule that only specially qualified persons or institutions have the right to offer legal services" ${ }^{\prime \prime 1}$. Destaco la necesidad de una declaración positiva y expresa del consumidor afectado.

\footnotetext{
79 Arts. 53 y 54 -nueva redacción- de la Ley argentina de Defensa del Consumidor.

80 Amrani Mekki, Rapport France; Cadiet, "Future Prospects for Collective Redress", pp. 6-7.

81 Baetge, "Germany", The Globalization of Class Actions, pp. 22-23.
} 
En Italia, la redacción del nuevo art. 140-bis del Codice del Consumo (2007) ha establecido que los consumidores perjudicados por ciertos hechos ${ }^{82}$, pueden pretender declaración de responsabilidad y condena a indemnización de daños y restituciones, mediante demanda presentada por una asociación -aunque no sea cualificada- a la que han otorgado mandato o por un comité en el que participan ${ }^{83}$. Otros consumidores pueden adherirse sin la forma ordinariamente prescrita para actuar como parte en un proceso. Para posibilitar esta adhesión se regula una adecuada publicidad. Sólo los consumidores adheridos serán afectados por la sentencia.

El estado de la cuestión en Derecho español, en el que falta claridad sobre aspectos importantes, es la siguiente:

1) Las asociaciones de consumidores y usuarios legalmente constituidas tienen legitimación activa para la defensa de derechos e intereses de titularidad de sus asociados, si estos han prestado conformidad a la demanda; pueden pretender cualquier clase de tutela; la sentencia afectará a los asociados que hubieran prestado conformidad a la demanda y tendrá valor de cosa juzgada frente a ellos ${ }^{84}$.

2) Las asociaciones de consumidores y usuarios constituidas según la Ley General de Consumidores tienen legitimación activa para la defensa de derechos e intereses en materia de consumo de titularidad de sus asociados (en las condiciones vistas) y también de titularidad de consumidores y usuarios determinados o determinables; pueden pretender cualquier clase de tutela (la Ley Procesal Civil habla de "perjudicados" y "daño", lo que implica pronunciamientos sobre validez de actos jurídicos perjudiciales y condena a indemnización o a otra prestación singularizada) ${ }^{85}$; la sentencia afectará a los asociados y a los consumidores y usuarios determinados o determinables y tendrá valor de cosa juzgada frente a ellos (art. 222.3 Ley Procesal Civil) ${ }^{86}$.

\footnotetext{
82 "2. L'azione tutela: a) i diritti contrattuali di una pluralità di consumatori e utenti che versano nei confronti di una stessa impresa in situazione identica (....); b) i diritti identici spettanti ai consumatori finali di un determinato prodotto nei confronti del relativo produttore, anche a prescindere da un diretto rapporto contrattuale; c) i diritti identici al ristoro del pregiudizio derivante agli stessi consumatori e utenti da pratiche commerciali scorrette o da comportamenti anticoncorrenziali".

83 LuPOI, Italy Report.

${ }^{84}$ Gutierrez de Cabiedes, Comentarios, I, pp. 153-155, que, además, puntualiza que se trata de intereses pluripersonales conexos, no colectivos.

85 Gutierrez de Cabiedes, Comentarios, I, p. 148-149; Gascón InChausti, F., Tutela judicial de los consumidores y transacciones colectivas, Civitas, Madrid, 2010, pp. 110-114.

${ }^{86}$ La ley no deja claro si establece un sistema opt-in u opt-out, pero la doctrina más solvente - GUTIERREZ DE CABIEDES, Comentarios, I, pp. 158, 159, 217-218; ; GASCón, Tutela judicial de los consumidores, pp. 125-127- se inclina por entender necesario bien el consentimiento expreso, bien el consentimiento tácito, consistente en no renunciar, ni desistir (o, tal vez, en una separación más informal) después de la información prevista en el art. 15 de la Ley Procesal Civil.
} 
3) La misma legitimación expuesta en el punto 2 la tienen otras entidades legalmente constituidas que tengan por objeto la defensa de consumidores y usuarios y grupos de afectados por el acto-hecho dañoso, que actúen por decisión mayoritaria de los afectados.

4) Las asociaciones de consumidores y usuarios constituidas según la Ley General de Consumidores y con la calidad de "más representativas" tienen la legitimación del punto 2, pero con una mayor amplitud subjetiva (derechos de consumidores y usuarios indeterminados o de difícil determinación).

En otros ordenamientos que hemos venido considerando, o no hay previsiones sobre esta especial legitimación ${ }^{87}$, o tienen un ámbito material de aplicación muy limitado ${ }^{88}$, o falta una más completa información sobre sus características $^{89}$.

C) Protección judicial de intereses supraindividuales en otras materias jurídicas

Este último bloque sistemático no pretende ser exhaustivo. En él trataré de regulaciones que establecen legitimaciones activas especiales que, comparadas con lo previsto en materia de consumo, tienen un ámbito de aplicación menor, pero que introducen nuevos supuestos de legitimación en el aspecto subjetivo. Además pueden concurrir con supuestos de legitimación considerados en los precedentes apartados $\mathrm{A}$ y $\mathrm{B}$.

a) Régimen de las condiciones generales de la contratación

En Francia, tienen legitimación activa para pretender la cesación del uso de cláusulas contractuales ilegales las asociaciones de consumidores que cumplan los requisitos del Code de la Consommation ${ }^{90}$.

En Alemania están legitimadas las asociaciones constituidas para la promoción de intereses comerciales y las asociaciones de consumidores ${ }^{91}$ para pretender la cesación del empleo de las cláusulas ilícitas ${ }^{92}$. Esa declaración, que subyace a la orden de cesación, puede ser invocada por los terceros a quienes beneficie ${ }^{93}$.

Para Italia, el art. 137 del Codice del Consumo dispone que: "Le associazioni dei consumatori, di cui all'art. 137, le associazioni rappresentative dei profes-

\footnotetext{
${ }^{87}$ Orfanidis, Griechenland Bericht.

${ }^{88}$ Véase lo que se expone al final del apartado IV.2.A.e.

${ }^{89}$ KULSKI, Poland Report.

90 Magnier, "France", The Globalization of Class Actions, pp. 6-7; AMrAnI MeKkI, Rapport France, que lamenta la falta de efectos respecto de terceros de la declaración de ilicitud de las cláusulas. Similarmente en Derecho japonés: Honma, Japan Report.

91 BAETGE, "Germany", The Globalization of Class Actions, p. 4.

92 BaetGe, "Germany", The Globalization of Class Actions, p. 22.

93 Baetge, "Germany", The Globalization of Class Actions, p. 14.
} 
sionisti e le camere di commercio, industria, artigianato e agricoltura, possono convenire in giudizio il professionista o l'associazione di professionisti che utilizzano, o che raccomandano l'utilizzo di condizioni generali di contratto e richiedere al giudice competente che inibisca l'uso delle condizioni di cui sia accertata l'abusività".

En Polonia, además de cada contratante y de entidades públicas, las asociaciones de consumidores tienen legitimación activa para pretender la cesación en el uso de cláusulas contrarias a ley, con eficacia para terceros desde la inscripción de la cláusula prohibida en un registro oficial ${ }^{94}$.

En Derecho español, además de cada contratante-sólo con efectos sobre su relación contractual-y de determinadas entidades públicas, tienen legitimación activa las asociaciones o corporaciones de empresarios, profesionales y agricultores que estatutariamente tengan encomendada la defensa de los intereses de sus miembros, los colegios profesionales y las Cámaras de Comercio, Industria y Navegación. Pueden pretender las tutelas de cesación, retractación (prohibición de recomendar el uso de cierta cláusula) y declarativa, ninguna de las cuales implica declaración sobre la validez de cláusula contractual, ni condena a indemnización. La sentencia afecta a los mismos afectados por la conducta ilícita -(en cesación y retractación) en cuanto que su ejecución les beneficiará indirectamente- y por la cláusula declarada condición general -porque no tendrán que demostrar ese carácter en un proceso en que sea relevante-. También tienen legitimación activa, para pretender las mismas tutelas ${ }^{95}$, las asociaciones de consumidores y usuarios que reúnan los requisitos de su ley especial.

b) Competencia desleal e infracción de las normas antitrust o de defensa de la competencia

En Alemania, además de los titulares de derechos afectados, las asociaciones constituidas para la promoción de los intereses comerciales y las asociaciones de consumidores cualificadas tienen legitimación activa para pretender condenas a cesación de conductas de competencia desleal ${ }^{96}$. En cambio, la legitimación colectiva se limita a las asociaciones de la primera clase y es problemática para las asociaciones de consumidores en cuanto a las acciones por infracción de las normas de defensa de la competencia ${ }^{97}$.

\footnotetext{
94 KULSKI, Poland Report.

95 No obstante, por la legitimación activa que otras normas atribuyen a estas asociaciones (véase apartado IV.2.B), las tutelas judiciales que pueden obtener son más amplias.

96 Baetge, "Germany", The Globalization of Class Actions, p. 4. No se pueden obtener condenas a indemnización de daños individualizados, aunque sí la imposición del deber de entregar a la Hacienda pública el importe de las ganancias ilegales (p. 23).
}

97 Baetge, "Germany", The Globalization of Class Actions, p. 6. 
En España la legitimación activa en materia de competencia desleal corresponde a las asociaciones de consumidores, además de a los titulares de derechos e intereses afectados y a determinadas entidades públicas. Pueden pretender la declaración de deslealtad de la conducta, su cesación, la remoción de sus efectos y la rectificación de las informaciones ilícitas. En materia de defensa de la competencia el problema es, en cierto modo, inverso al de Alemania ${ }^{98}$.

En Grecia, la legitimación activa de las asociaciones de comercio e industria y de otros participantes en el funcionamiento del mercado para las acciones de cesación de conductas de competencia desleal está prevista desde hace tiempo, pero no tiene una práctica frecuente. ${ }^{99}$

Los trabajos preparatorios del borrador de la Ley Tipo de Defensa de la Competencia no consideran la legitimación activa de asociaciones, sino sólo la de los particulares y la del Estado "en el ejercicio de funciones tutelares (parens patriae suit)"100.

c) Protección del ambiente y del patrimonio histórico-artístico

Respecto de estas materias, la información para algunos ordenamientos es escasa, ${ }^{101} \mathrm{o}$ la respuesta es claramente negativa ${ }^{102}$.

En Argentina rige la Ley General del Ambiente ${ }^{103}$, atribuye legitimación activa, además de a los afectados y ciertas entidades públicas, a las asociaciones de defensa del ambiente, que pueden pretender la cesación de la conducta causante del daño, la restauración del estado anterior y la indemnización del daño ambiental. La sentencia estimatoria tiene efectos, y produce cosa juzgada, erga omnes, aunque se ha debatido si los legitimados mencionados pueden pretender condena a indemnización de los daños individuales que no sean los propios $^{104}$.

\footnotetext{
${ }_{98}$ La reforma del Derecho de defensa de la competencia ha posibilitado el ejercicio de acciones ante los tribunales civiles, pero no se ha establecido ninguna norma especial adicional sobre legitimación activa, de modo que, además de los titulares individuales de derechos e intereses lesionados, sólo entran en juego las normas de legitimación activa en materia de protección de consumidores (véase apartado IV.2.B). En Italia las normas de legitimación en protección de consumidores se aplican, también, en defensa de la competencia (art. 140-bis, 2, c del Codice del Consumo).

99 OrfanidIs, Griechenland Bericht.

100 UNCTAD, Model Law on Competition, p. 76: "Under such "class actions", users or consumers of a specific service or good who have suffered damage from anticompetitive behaviour, and whose individual claim would be too insignificant, have the right to institute action against enterprises".

101 Honma, Japan Report.

102 Filatova, Russia Report.

103 En opinión de Merol, Informe Argentina, en materia de defensa del patrimonio histórico y antidiscriminación, en defecto de legislación específica, se admite ampliamente la legitimación de las asociaciones que incluyan en su objeto estatutario la protección de ese tipo de intereses.
}

104 Merol, Informe Argentina. 
En Colombia, la tutela judicial de intereses colectivos respecto del ambiente -también respecto del "patrimonio cultural de la Nación"- puede ser pretendida, mediante acción popular, por cualquier persona, organizaciones no gubernamentales y determinadas entidades públicas. La tutela de derechos individuales homogéneos, incluso mediante indemnización de daños derivados del ilícito ambiental, puede obtenerse mediante una acción de grupo ${ }^{105}$.

En Derecho francés, asociaciones constituidas para la defensa del ambiente y que cumplan ciertos requisitos pueden pretender la tutela de intereses colectivos frente a conductas infractoras de las normas de protección de la naturaleza y del ambiente ${ }^{106}$.

En Italia, la legitimación de asociaciones cualificadas para la defensa del ambiente y del patrimonio histórico-artístico parece limitada a la acción ante los tribunales de la jurisdicción administrativa ${ }^{107}$. Esta limitación a la jurisdicción administrativa, aunque no la legitimación, que se atribuye con mayor amplitud, es también característica del Derecho español ${ }^{108}$.

En Derecho alemán "since 2002, the Federal Environmental Protection Law confers the right upon qualified environmental interest groups to enforce environmental standards and rules in the courts without having to assert an injury to their own proprietary interests" 109 .

Precisamente, el requisito del consentimiento del reclamante hace poco comprensible, en el Derecho de Polonia, la legitimación para intervenir en los procesos correspondientes de las organizaciones sociales para la defensa del ambiente $^{110}$.

Por lo demás, la Convención sobre el acceso a la información, la participación del público en la toma de decisiones y el acceso a la justicia en asuntos ambientales, adoptada el 25 de junio de 1998 111 , establece disposiciones relevantes sobre el acceso a los tribunales en asuntos ambientales incluso si la causa de la reclamación es la acción u omisión de particulares (art. 9.3). Su art. 2 se refiere a los posibles legitimados activos, que pueden ser "una o varias

\footnotetext{
105 Parada Caicedo, Informe Colombia. Además, véase el apartado IV.2.B.b.

106 Amrani Mekki, Rapport France; Magnier, "France", The Globalization of Class Actions, p. 7.

107 LupOI, Italy Report.

108 Arts. 22 y 23 de la Ley 27/2006, de 18 julio, por la que se regula los derechos de acceso a la información, de participación pública y de acceso a la justicia en materia de medio ambiente.

109 BaEtGe, "Germany", The Globalization of Class Actions, p. 7.

110 Kulski, Poland Report; Sengayen, "Poland", The Globalization of Class Actions, pp. 26-27, 32-35, 48. En efecto, la cuestión es quién puede ser el demandante cuando se trata de la defensa de intereses colectivos.

111 http://www.unece.org/env/pp/welcome.html
} 
personas físicas o morales y, con arreglo a la legislación o la costumbre del país, las asociaciones, organizaciones o grupos constituidos por esas personas".

d) Referencia a la protección de derechos supraindividuales en materia laboral y de propiedad intelectual

Un especial régimen de la legitimación activa para pretender determinadas tutelas judiciales colectivas tiene gran importancia en las dos materias mencionadas en el epígrafe ${ }^{112}$. En materia laboral goza de gran tradición. La protección de los derechos colectivos de propiedad intelectual es más reciente, pero ha adquirido un amplio desarrollo. Las cuestiones son desbordantes, pero lo que me limito a una referencia.

En materia laboral, parece claramente trazada la distinción entre la legitimación activa de sindicatos y asociaciones empresariales para pretender tutelas judiciales de carácter colectivo -conflictos y convenios colectivos, defensa de derechos sindicales, etc. ${ }^{113}$ y la facultad de aquellas entidades -especialmente, de los sindicatos- de actuar en un proceso para pretender la tutela de derechos individuales de cada trabajador. Lo último o está excluido ${ }^{114}$, o acotado a una intervención procesal de alcance limitado ${ }^{115}$, o su eficacia se hace depender del expreso consentimiento del trabajador interesado ${ }^{116}$.

En la compleja constelación de derechos derivados de la propiedad intelectual, la legitimación para pretender la tutela de algunos de ellos corresponde a sus titulares individualmente considerados. Otros derechos de propiedad intelectual tienen necesariamente una gestión colectiva ${ }^{117}$, que es encomendada a entidades que deben cumplir requisitos que garanticen el cumplimiento de su función en favor de los autores y que suelen ser supervisadas por las Adminis-

\footnotetext{
112 Me ha parecido adecuado incluir aquí la consideración de la protección de los derechos colectivos de propiedad intelectual, porque, en definitiva, significa una protección del trabajo creativo no dependiente.

113 CADIET, "Future Prospects for Collective Redress", p. 6, nota 15; Orfanidis, Griechenland Bericht; Lupol, Italy Report; Filatova, Russia Report; Merol, Informe Argentina. En España, el art. 17 de la Ley Procesal Laboral dispone que "los Sindicatos de trabajadores y las Asociaciones empresariales tendrán legitimación para la defensa de los intereses económicos y sociales que les son propios" -después se detalla el régimen de esta legitimación en cuanto a la promoción de procesos sobre conflictos colectivos e impugnación de convenios colectivos.

114 Lupol, Italy Report, FILATOVA, Russia Report.

115 Orfanidis, Griechenland Bericht. En Derecho español, si la violación del derecho de libertad sindical afecta a derechos e intereses individuales de un trabajador, el sindicato puede intervenir, pero no continuar el proceso si la parte principal lo abandona (art. 175 Ley Procesal Laboral).

116 Merol, Informe Argentina; Amrani Mekki, Rapport France; Sengayen, "Poland", The Globalization of Class Actions, p. 33.

117 P. ej., compensación por copia privada de diversas clases de obras, remuneración por comunicación pública de fonogramas, por proyección de obras audiovisuales sin pago de entrada al local, por operaciones de alquiler y préstamo de obras de las dos últimas clases mencionadas.
} 
traciones públicas ${ }^{118}$. A estas entidades se atribuye legitimación para pretender la tutela de tales derechos colectivos, incluida la condena al pago de cantidades adeudadas en virtud de los mismos.

e) Protección frente a actos y conductas discriminatorias

La falta de previsión legal conduce, en algunos ordenamientos, a negar específicas legitimaciones para pretender tutela judicial frente a tratos discriminatorios ${ }^{119}$. Sin embargo, en Argentina, la genérica previsión constitucional permite considerar legitimadas a las asociaciones cuyo objeto social incluya la defensa de los grupos que padecen discriminación ${ }^{120}$.

En varios ordenamientos, que cuentan con regulación expresa, la legitimación activa se atribuye-además de a los propios afectados, y, a veces, a entidades públicas-a asociaciones que cumplan específicos requisitos. No obstante, estas asociaciones no pueden presentar la demanda por su exclusiva decisión, sino que -tal vez porque las normas contemplan, exclusiva o principalmente, los actos discriminatorios sufridos por personas determinadas- necesitan la expresa conformidad de la persona afectada ${ }^{121}$.

Se prescinde de la última exigencia si la acción o conducta discriminatoria tiene sujetos pasivos indeterminados y difícilmente determinables ${ }^{122}$, lo que ocurre, en todo caso, si la conducta ilícita consiste en una actividad publicitaria atentatoria a la dignidad del conjunto de personas cuyo trato igual la ley $\operatorname{protege}^{123}$.

118 En Francia, sociedades civiles autorizadas por el Ministerio competente; en Italia, la Sociedad italiana de autores y editores; en Alemania, la entidades de gestión acreditadas por las Administraciones públicas competentes; en España, las entidades de gestión de los derechos de autor -ArmenGOT VILAPLANA, A., La tutela civil de la propiedad intelectual, La Ley, Madrid, 2003, pp. 229-265-; en Colombia, las sociedades de gestión autorizadas por la Administración; en Argentina, la Sociedad Argentina de Autores y Compositores de Música, sobre la que el Estado ejerce fiscalización permanente; en Brasil, las asociaciones de gestión colectiva constituidas al amparo de la Ley de 19 de febrero de 1998.

119 Filatova, Russia Report.

120 Merol, Informe Argentina.

121 Kulski, Poland Report; Amrani Mekkı, Rapport France. En Derecho español, los sindicatos y asociaciones legalmente constituidas con el fin de defensa de igualdad de género tienen legitimación activa para defender a sus afiliados y asociados, si estos lo autorizan; norma similar la establece el art. 19 de la Ley de protección de la igualdad de los discapacitados.

122 P. ej., en Derecho español, los organismos públicos competentes, los sindicatos más representativos y las asociaciones de ámbito estatal legalmente constituidas con el fin de defensa de igualdad de género tienen legitimación activa para defender los intereses de afectados indeterminados o de difícil determinación. Otra cosa es que los afectados aprovechen o no los efectos favorables de la sentencia que pueda dictarse.

123 También sirve un ejemplo de Derecho español: Además de algunas entidades públicas, las asociaciones que cumplan específicos requisitos legales tendrán legitimación activa para defender -mediante acción de cesación- los intereses colectivos y difusos de las mujeres en caso de publicidad ilícita por utilización vejatoria o discriminatoria de la imagen de la mujer. 


\section{Los ajustes en la estructura del procedimiento}

Los ajustes para conseguir un tratamiento más adecuado de los objetos litigiosos que estamos considerando son especialmente convenientes si, como es frecuente, entre los intereses supraindividuales se consideran incluidos los derechos e intereses individuales homogéneos o conexos, cuando se pretende la tutela de una pluralidad de los mismos.

Los ajustes serán diferentes según se haya optado por atribuir legitimación a una persona o entidad, para que, de entrada, pueda pretender la tutela judicial de un conjunto de derechos individuales de la calidad mencionada, o, diferentemente, sólo se reconozca legitimación a cada uno de los titulares, lo que deja abierta la posibilidad de que sea presentada una pluralidad de demandas, con elementos comunes o iguales (demandado, fundamentos de la pretensión).

A) Especialidades del procedimiento en el supuesto de demanda de un legitimado para pretender la tutela de una pluralidad de derechos individuales homogéneos o conexos

Las principales especialidades consisten en:

1) La previsión de una etapa procedimental para examinar los requisitos específicos de admisión de la demanda, particularmente la representatividad del actor, si las normas confieren al juez un ámbito de apreciación sobre su legitimación ${ }^{124}$.

2) Un régimen para la adhesión o el desistimiento de los titulares de los derechos individuales, previa regulación de las formas de comunicación a los mismos de la pendencia del proceso. También puede regular su intervención individual en el proceso ${ }^{125}$.

3) La bipartición de la actividad procesal declarativa. Una primera etapa sirve para la declaración sobre la responsabilidad del demandado, la condena genérica a indemnizar ${ }^{126}$ y, tal vez, para establecer parámetros de concre-

\footnotetext{
${ }_{124}$ Así, p. ej., el art. 11 del borrador de Código Modelo de Procesos Colectivos para Iberoamérica (art. 11), y el art. 140-bis, apartado 6 del Codice del Consumo italiano.

125 Arts. 94 y $133 \S 2^{\circ}$, a contrario sensu, del brasileño Código do Consumidor. En Argentina, una Ley de 2008, que modifica diversos artículos de la Ley de defensa del consumidor de 1993, atribuye al juez la potestad de establecer el tiempo y la forma de manifestar el apartamiento de los titulares de derechos individuales. En Derecho colombiano, los arts. 53, 55 y 56 de la Ley sobre ejercicio de las acciones populares y de grupo. En el borrador de Código Modelo de Procesos Colectivos para Iberoamérica, los arts. 20, 21 y 31. Para Italia hay que atender a lo dispuesto por los apartados 3 y 9 del art. 140-bis del Codice del Consumo. En España, el art. 15 de la Ley Procesal Civil regula la información a los consumidores cuyos derechos individuales pueden ser afectados, su facultad de intervención en el proceso, pero no el tiempo y forma de la autoexclusión, que debe considerarse sujeta a las normas generales sobre desistimiento y renuncia, en su caso.

126 Art. 95 del brasileño Código do Consumidor, y sobre el mismo, Pellegrini Grinover, "Brazil and Iberoamerica", The Globalization of Class Actions, pp. 7-8, y GIDI, Las acciones colectivas, pp. 62-63.
} 
ción de las indemnizaciones individuales ${ }^{127}$. Una segunda etapa, también declarativa, tiene por objeto la cuantificación de las indemnizaciones individuales ${ }^{128}$, o incluso, previamente, la declaración de que la situación de la persona que reclama la indemnización encaja en los parámetros fijados por la sentencia ${ }^{129}$.

B) Los tratamientos eficientes de la pluralidad de objetos procesales

Si las pretensiones de los titulares de derechos e intereses individuales han de ser planteadas por cada uno de ellos, dado que los ilícitos que les dan fundamento son masivos, un gran número de demandas puede ser presentado y originar sobrecarga de trabajo en los tribunales. Dos clases de técnicas persiguen un tratamiento eficiente de esa situación.

a) La acumulación de objetos procesales

Esta técnica sólo parcialmente produce economías en la actividad procesal, aunque en todo caso tiene el efecto general de reducir el riesgo de sentencias contradictorias.

La acumulación de pretensiones en una única demanda es muy útil porque unifica la actividad procesal de las partes y del juez, tanto la actividad de alegación y de prueba y de dirección procesal, cuanto la de formación de la sentencia final. No obstante, su práctica puede tener dificultades, en primer término, si la regulación de esta acumulación es restrictiva ${ }^{130}$; en segundo lugar por la necesidad de concertar a los legitimados para presentar una demanda única con las pretensiones de todos ellos, objetivo difícil si esas pretensiones se fundan en actos ilícitos de alcance masivo ${ }^{131}$.

La acumulación de procesos ya pendientes ${ }^{132}$ no produce necesariamente economías ni en la actividad procesal de las partes -que siguen actuando de

${ }^{127}$ En Colombia, el art. 65 de la Ley sobre ejercicio de las acciones populares y de grupo. En Derecho argentino, el art. 54 de la Ley de Defensa del Consumidor. En Italia, el art. 140-bis, apartado 12 del Codice del Consumo. Y el art. 221, apartado 1, regla 1 ${ }^{\mathrm{a}}$, de la Ley Procesal Civil española.

128 CAPONI, R., "The Collective Redress action in the Italian Legal System", en ZZPInt 13 (2008), p. 17.

129 Pellegrini Grinover, "Brazil and Iberoamerica", The Globalization of Class Actions, p. 8. Para Argentina, art. 54 de la Ley de Defensa del Consumidor. En el borrador de Código Modelo de Procesos Colectivos para Iberoamérica el art. 23. En Derecho español, los aarts. 221 y 519 de la Ley Procesal Civil regulan la extensión de la eficacia ejecutiva de la sentencia a consumidores no designados en la sentencia, pero que hayan sufrido los daños que la sentencia condena a indemnizar.

130 Merol, Informe Argentina; Amrani Mekkı, Rapport France; Kulskı, Poland Report. Parece que en Rusia esta acumulación tiende a facilitarse; así indica Filatova, Russia Report.

131 Otra dificultad, originada por el carácter masivo, es la complejidad que introduce en el debate procesal, que puede inducir al tribunal a la separación de procedimientos: HONMA, Japan Report.

132 En general facilitada en varios ordenamientos, como se deduce de las informaciones generales de Amrani Mekkı, Rapport France, Filatova, Russia Report, Kulski, Poland Report, Honma, Japan Report. 
modo individual, aunque dentro de trámites (escritos u orales) únicos-, ni en la gestión del tribunal -que debe ocuparse de la actividad procesal de cada una de las partes constituida en el proceso separadamente ${ }^{133}$.

Por otra parte, la acumulación puede generar retrasos en algunos de los procesos acumulados o en todos ellos, a causa del propio régimen de la acumulación o de las incidencias en su aplicación.

b) Suspensión de la mayor parte de procesos y tramitación de un proceso "modelo" ("sonda", "test", o "muestra")

La técnica de proceso o caso "modelo" permite superar el inconveniente de la acumulación de procesos consistente en la actividad procesal individualizada de cada parte constituida y en la gestión procesal, igualmente singularizada, por parte del tribunal.

Es paradigmático el régimen establecido en Alemania por la Ley de caso modelo en litigios de mercado de capitales. Muy sintéticamente: ${ }^{134}$ El tribunal de la apelación determina el "caso modelo" -para lo que atenderá a los elementos que concurren en él y tienen relevancia común para los casos presentados en las diversas demandas-, así como al actor que lo defenderá; el proceso sobre el "caso modelo" es tramitado, y se suspende la tramitación de las otras demandas, aunque sus actores pueden actuar como intervinientes adhesivos en el proceso en curso; la sentencia del proceso sobre el "caso modelo" -recurrible en revisión ante el Tribunal Supremo Federal-vincula a todas las partes que hubieran presentado demandas, salvo que desistan de las mismas en ciertas condiciones legales. En una última etapa, el tribunal-con vinculación a las cuestiones con relevancia común resueltas en la sentencia del "caso modelo"- dicta sentencia en los procesos que quedaron suspendidos y continúen pendientes.

En otros ordenamientos europeos, una técnica similar se halla establecida en el proceso contencioso-administrativo, pero no en el proceso civil ${ }^{135}$. Así ocurría, por cierto, también en Alemania ${ }^{136}$. La explicación radica en que el proceso contencioso-administrativo ha experimentado antes que el civil la necesidad de enfrentarse de manera eficiente con los procesos-masa.

\footnotetext{
133 Baetge, "Germany", The Globalization of Class Actions, p. 12.

134 Baetge, "Germany", The Globalization of Class Actions, pp. 7-10, 12-16, 18-20, 22 ; Hess, B., "Private law enforcement" und Kollektivklagen", Juristenzeitung, 2/2011, pp. 68-69.

135 Amrani Mekki, Rapport France. Para España, la regulación está en los arts. 37 y 111 de la Ley Procesal Administrativa, sobre los que véase ROSENDE VILLAR, C., La eficacia frente a terceros de las sentencias contencioso-administrativas, Aranzadi, 2002, pp. 232-246. Merol, Informe Argentina, informa de aproximaciones a esta técnica en la práctica judicial.

136 Baetge, "Germany", The Globalization of Class Actions, p. 19.
} 


\section{La prueba en el proceso civil para la protección de intereses} supraindividuales: dificultades y normas especiales para superarlas

En los estudios sobre las materias jurídicas para las que se preconiza o se valora la conveniencia de que la aplicación de las normas correspondientes sea realizada por los tribunales civiles y mediante su proceso, nunca faltan consideraciones acerca de, por un lado, el reforzamiento de los derechos del actor y de las potestades del tribunal para la obtención de pruebas en poder del demandado y de difícil acceso para el $\operatorname{actor}^{137}$, y, por otro lado, sobre la introducción de reglas especiales de carga de la prueba o que faciliten, de otro modo, la obtención de unos resultados probatorios especialmente difíciles de alcanzar y que son imprescindibles para que el tribunal pueda acoger ciertas pretensiones ${ }^{138}$.

A) Facilitación del acceso a las pruebas

En primer término, antes de la presentación de la demanda y para que ésta sea admisible y cuente con suficiente fundamento, el actor puede necesitar el acceso a datos en poder del demandado o de terceros, con vistas a:

1) Determinar e identificar a las personas afectadas, principalmente para informarlas de la presentación de la demanda, de modo que puedan adherirse o excluirse de la misma. Algunos ordenamientos carecen de previsiones específicas sobre esta cuestión ${ }^{139}$, a la que otros sí dedican normas ${ }^{140}$.

2) Comprobar suficientemente las expectativas de éxito de las pretensiones que proyecte interponer, en cuanto esto condiciona la decisión de iniciar un proceso cuyo coste será elevado y con riesgos económicos adicionales en caso de fracaso. En algunos casos el futuro demandante carece de la posibilidad de conocer y obtener determinadas pruebas, que se hallan en ámbitos a los que sólo se puede acceder con intervención judicial. Esta necesidad no es atendida en algunos ordenamientos ${ }^{141}$, en otros se destaca la accesibilidad de los datos

\footnotetext{
137 Véase, p. ej., en materia de defensa de la competencia, Möllers, Heinemann, Eds., The Enforcement of Competition Law, pp. 649-650; White Paper on Damages ... EC antitrust rules, 2.2. En relación con estas cuestiones, en su tratamiento en el Libro Verde antecedente del que se acaba de citar, EGER, WEISE, "Limits to the private enforcement of antitrust law", pp. 3-4; HodGES, "Competition Enforcement", p. 1383; Alfaro, "Contra la armonización positiva", pp. 14-15.

138 P. ej., en materia de protección del ambiente, HintereGGer, (Ed.), Environmental Liability, pp. 610-612. En materia de publicidad ilícita y competencia desleal, Möllers, Heinemann, Eds., The Enforcement of Competition Law, pp. 60, 65-66. Y en defensa de la competencia, de nuevo Möllers, Heinemann, Eds., The Enforcement of Competition Law, pp. 649-650; White Paper on Damages ...EC antitrust rules, 2.4.

139 Merol, Informe Argentina; Fllatova, Russia Report.

140 Así, el art. $256.6^{\circ}$ de la Ley Procesal Civil española y el art. 20 del Borrador del Código Modelo de Procesos Colectivos para Iberoamérica, versión Caracas 28 de octubre de 2004.

141 FILATOVa, Russia Report. En Derecho español están previstas diligencias preliminares en material de propiedad industrial e intelectual, pero no en general, ni en las materias que estamos tratando ahora.
} 
en poder de las Administraciones públicas ${ }^{142}$; otros, en fin, ofrecen respuestas positivas, aunque deben matizarse desde una perspectiva realista ${ }^{143}$.

En segundo lugar, ya dentro del proceso iniciado, hay dos clases de regulaciones que pueden contribuir a una instrucción probatoria tendencialmente completa:

1) La potestad del tribunal de ordenar de oficio la práctica de pruebas, que es regla general en algunos procesos civiles ${ }^{144}$, o que se establece especialmente, con diferente alcance, en procesos sobre las materias que estamos considerando ${ }^{145}$.

2) Facultad de las partes y potestades del tribunal para obtener la aportación de pruebas en poder de la otra parte o de terceros. En algunos ordenamientos es una regulación general del correspondiente proceso civil ${ }^{146}$, en otros está prevista en disposiciones específicas ${ }^{147}$.

B) Facilitación de los resultados probatorios

Ocupan lugar destacado las normas especiales sobre distribución de la carga de la prueba en materias de responsabilidad extracontractual ${ }^{148}$, de responsabilidad contractual en contratos con consumidores ${ }^{149}$, y en los casos en que deben apli-

142 Merol, Informe Argentina. Por otra parte, la Convention on Access to Information, Public Participation in Decision-Making and Access to Justice in Environmental Matters establece disposiciones relevantes sobre el acceso a la información que las Administraciones han debido recabar y conservar acerca de los asuntos mencionados; los Estados signatarios se comprometen a facilitarlo al "público interesado" en los términos de los artículos 4 y 5 de la Convención, con control jurisdiccional de la inactividad administrativa.

${ }^{143}$ Honma, Japan Report. En Derecho brasileño, el art. 8 de la Lei de Ação Civil Pública se refiere a las potestades de investigación del Ministerio Público; no obstante, el alcance práctico de esta previsión normativa parece que es limitado, si atiende a lo dice GIDI, Las acciones colectivas, p. 107: "La ausencia de este poderoso instrumento en Brasil (MOR: se refiere al sistema de discovery) resulta en decisiones a menudo basadas en pruebas e información limitadas".

144 Amrani Mekki, Rapport France; Parada Calcedo, Informe Colombia.

145 Orfanidis, Griechenland Bericht, MEROI, Informe Argentina. La prueba de oficio es también la opción del borrador del Código Modelo de Procesos Colectivos para Iberoamérica (art. 12, párrafo 3).

146 Amrani Mekkı, Rapport France; Kulskı, Poland Report. También Filatova, Russia Report, aunque destaca que el tribunal "is not obliged to grant such taking: decision is left on the court's discretion".

147 Honma, Japan Report; Merol, Informe Argentina. Por otra parte, hay que recordar lo que apuntamos poco antes respecto de la Convention on Access to Information, Public Participation in Decision-Making and Access to Justice in Environmental Matters.

148 Orfanidis, Griechenland Bericht.

149 Orfanidis, Griechenland Bericht. En la Ley General de Protección de Consumidores española, las normas especiales sobre carga de la prueba son abundantes (arts. 76, 80, 82, 88, 100), y la Ley Procesal Civil dispone que "en los procesos sobre competencia desleal y sobre publicidad ilícita corresponderá al demandado la carga de la prueba de la exactitud y veracidad de las indicaciones y manifestaciones realizadas y de los datos materiales que la publicidad exprese, respectivamente". 
carse normas de protección frente a conductas discriminatorias ${ }^{150}$. Estas normas especiales pueden ser menos necesarias si el régimen general de la distribución de la carga de la prueba autoriza al tribunal a asignar la carga a la parte que, en concreto, tenga más facilidad de probar ciertos hechos ${ }^{151}$.

Por otra parte, se puede facilitar el alcance de resultados probatorios difíciles reduciendo la intensidad o fuerza de la convicción que, por regla general, sea requerida para entender que determinado hecho ha sido probado ${ }^{152}$.

Por fin -dejando aparte las ventajas probatorias que derivan de un régimen material de responsabilidad objetiva ${ }^{153}$ o de acotación de las exenciones de responsabilidad- ${ }^{154}$, también facilita la obtención de resultados probatorios la exclusión de la cosa juzgada si la sentencia establece expresamente que la pretensión no ha podido ser estimada por insuficiencia de pruebas ${ }^{155}$. Éste non liquet sobre la cuestión de hecho, por falta de prueba, deja abiertas nuevas opciones para accionar con probable éxito en el futuro.

150 AmRani MeKkı, Rapport France. En Derecho español, sin citar artículos concretos de leyes, sí que es útil reproducir su contenido: "De acuerdo con las leyes procesales, en aquellos procedimientos en los que las alegaciones de la parte actora se fundamenten en actuaciones discriminatorias por razón del sexo, corresponderá al demandado probar la ausencia de discriminación en las medidas adoptadas y de su proporcionalidad"; $y$ "en aquellos procesos en que de las alegaciones de la parte actora se deduzca la existencia de indicios fundados de discriminación por razón de sexo, origen racial o étnico, religión o convicciones, discapacidad, edad u orientación sexual, corresponderá al demandado la aportación de una justificación objetiva y razonable, suficientemente probada, de las medidas adoptadas y de su proporcionalidad".

151 Merol, Informe Argentina; MaIral, "Argentina", The Globalization of Class Actions, p. 21; PARADA CAICEDO, Informe Colombia. La Ley Procesal Civil española establece reglas legales de distribución de la carga de la prueba, pero también dispone que el tribunal "deberá tener presente la disponibilidad y facilidad probatoria que corresponde a cada una de las partes". El borrador de Código Modelo de Procesos Colectivos para Iberoamérica (art. 12, párrafo 1) opta directamente por la regla de la facilidad probatoria.

152 Honma, Japan Report; Merol, Informe Argentina. También en materia de protección del ambiente tiene utilidad la revisión que se hace en HintereGger, (Ed.), Environmental Liability, pp. 609-615, del tratamiento de los niveles de certeza, facilitación de la carga de la prueba y consideración de la prueba estadística en diversos ordenamientos europeos. Por cierto, el borrador de Código Modelo de Procesos Colectivos para Iberoamérica (art. 12) incluye una expresa disposición en el sentido de que: "Son admisibles en juicio todos los medios de prueba, incluida la prueba estadística o por muestreo".

153 P. ej., aunque la técnica está muy generalizada, HonmA, Japan Report.

154 Orfanidis, Griechenland Bericht.

155 Así, según el art. 16 de la brasileña Lei de Ação Civil Pública y, en el mismo sentido, el art. 103 del Código do Consumidor. Para la justificación de estas normas, GıDı, Las acciones colectivas, pp. 104108. La solución ha sido también acogida en el borrador de Código Modelo de Procesos Colectivos para Iberoamérica (art. 33). 


\section{Especialidades en el recurso ante el más alto tribunal ordinario}

La cuestión básica es si, habida cuenta del interés social o público que está en juego en los procesos para la protección de intereses supraindividuales, el acceso al más alto tribunal está permitido con mayor amplitud que en otros procesos civiles o ese tribunal ejerce los poderes discrecionales de los que pueda estar investido en sentido más favorable a la admisión.

Las respuestas positivas que he podido registrar no revelan que ese tratamiento se halle muy extendido, ni en cuanto a los ordenamientos en que se dice que hay muestras del mismo, ni en cuanto a las materias jurídicas en que ese trato más favorable a la recurribilidad se establece de manera legalmente clara ${ }^{156}$.

Una segunda cuestión, también justificada por la amplia incidencia subjetiva de las cuestiones jurídicas que se tratan en estos procesos, es la de si, en virtud de norma legal o por una práctica jurídica aceptada, se atribuye algún valor vinculante a las sentencias que dicte el más alto tribunal ${ }^{157}$. Específicamente, en Derecho griego y en Derecho español ese valor vinculante se introduce por la vía indirecta de habilitar al Poder Ejecutivo para imponer modificaciones en las condiciones generales de contratación que han sido declaradas ilícitas ${ }^{158}$. En Derecho español se ha llegado a establecer, en un supuesto, norma directa sobre vinculación al precedente ${ }^{159}$.

\section{El fortalecimiento de la efectividad de la tutela judicial}

La preferencia por atribuir a las Administraciones públicas la actuación del Derecho que protege intereses supraindividuales, fundada en la mayor efectividad de la acción administrativa (apartado III.4) puede cambiar si se comprueba que los tribunales están investidos de potestades adecuadas para que la tutela judicial sea más efectiva. Las principales regulaciones a considerar son el régimen de las medidas provisionales - sin duda, la vía más idónea para salvar la falta de agilidad de la respuesta judicial- y la intensidad de los medios ejecutivos de los que el tribunal dispone para forzar el cumplimiento de las sentencias y de las resoluciones cautelares.

156 Merol, Informe Argentina; Filatova, Russia Report. Normas más específicas que establecen la recurribilidad las encontramos, en Derecho alemán, en el § 15 (1) de la Ley de procedimiento sobre caso modelo respecto de inversores en mercado de capitales (BAETGE, "Germany", The Globalization of Class Actions, p. 13), y en Derecho español (art. 18.3 de la Ley de Condiciones Generales de la Contratación).

157 Me refiero a un valor como precedente jurisprudencial, no a la extensión subjetiva de la cosa juzgada de estos procesos más allá de quienes han sido parte en los mismos.

158 Orfanidis, Griechenland Bericht. Para el Derecho español, véase la disposición mencionada en el apartado IV.1.D.

159 Art. 20.4 de la Ley de Condiciones Generales de la Contratación. 
En cuanto al régimen de las medidas provisionales, por regla general no están previstas normas especiales en los supuestos de protección de intereses supraindividuales ${ }^{160}$, aunque el régimen común se considera satisfactorio para la protección de aquellos intereses ${ }^{161}$, La dificultad de que el solicitante de tutela provisional deba prestar caución para garantizar eventuales daños al sujeto pasivo de la medida, no siempre se plantea, sea porque el requisito no siempre es legalmente preceptivo, ${ }^{162}$ sea porque es específicamente excluido ${ }^{163}$.

Respecto de la disponibilidad de instrumentos ejecutivos más potentes e incisivos, las respuestas han sido, por lo general, negativas ${ }^{164}$, lo que no es necesariamente significativo de una protección menos efectiva, salvo que los instrumentos ejecutivos de carácter general no sean suficientemente intensos ${ }^{165}$. Hay, sin embargo, algún apunte en el sentido de un mayor rigor de esos instrumentos $^{166}$, principalmente agravando el régimen de las multas coercitivas ${ }^{167}$.

\section{Los costes del proceso y su financiación}

La consideración de los costes del proceso es muy influyente en la evaluación de la conveniencia de iniciar o no un proceso. La consideración adquiere mayor peso y se realiza con más objetividad si, como ocurre en la mayor parte de supuestos que estamos contemplando aquí, quien tiene la legitimación ac-

\footnotetext{
160 Merol, Informe Argentina; Kulski, Poland Report; Lupol, Italy Report; Filatova, Russia Report. Sin embargo, por su propia finalidad de contribuir a la mejora de ordenamientos nacionales que probablemente tienen un sistema deficiente de tutela provisional, el borrador de Código Modelo de Procesos Colectivos para Iberoamérica sí que propone un régimen de medidas anticipatorios con amplios efectos (art. 5).

161 Merol, Informe Argentina; Lupol, Italy Report, Filatova, Russia Report, Amrani MekKI, Rapport France.

162 Lupol, Italy Report; Filatova, Russia Report.

163 Merol, Informe Argentina; Parada Caicedo, Informe Colombia. El art. 728 de la Ley Procesal Civil española establece que la caución es discrecional para el juez en caso de medidas cautelares de acciones de cesación en defensa de intereses de consumidores.

164 Merol, Informe Argentina; Filatova, Russia Report.

165 Dado que tendría que llenar eventuales vacios en ordenamientos nacionales, es comprensible que el borrador de Código Modelo de Procesos Colectivos para Iberoamérica sí que proponga un régimen de multas coercitivas severo (art. 60).

166 Véanse el régimen de las multas coercitivas y de otros instrumentos ejecutivos en el art. $84.4^{\circ}$ y $5^{\circ}$ del brasileño Código do Consumidor y en el art. 11 de la brasileña Lei de Ação Civil Pública. AmRANI MeKKI, Rapport France.

167 Honma, Japan Report. El art. 711 de la Ley Procesal Civil española amplía los supuestos en que pueden imponerse multas coercitivas, asi como el importe de las mismas.
} 
tiva no es el titular, o no es el titular exclusivo, de los derechos e intereses cuya tutela judicial puede pretender ${ }^{168}$.

A) Costes inicialmente a cargo del actor y normas especiales a favor del actor en esta materia

Las partidas más importantes de los costes que, en principio, han de ser asumidos por el actor son la retribución de los abogados, los gastos de la publicidad de la presentación de la demanda -si ha de aplicarse un sistema opt-in u opt-out-, y los gastos de la prueba pericial.

La retribución de los abogados podría dejar de ser un factor muy disuasorio si en los ordenamientos se considerara válido el pacto de quota litis en su versión más estricta. El panorama normativo sobre esta materia es muy diversificado: ordenamientos con plena libertad para pactar los honorarios ${ }^{169}$; otros que no fijan mínimos imperativos, aunque limitan los porcentajes de participación en las cantidades que se obtengan ${ }^{170}$; otros no prohíben la fijación en función de esos porcentajes, pero que el abogado no cobre si el pleito se pierde ${ }^{171}$.

Los ordenamientos que estamos considerando ${ }^{172}$ no contemplan la posibilidad de que los gastos a cargo del actor sean financiados mediante contratos de naturaleza aleatoria, en los que el financiador asuma los costes con la contraprestación (futura e incierta) de un porcentaje de lo que se obtenga en el proceso.

La asunción de los costes por los legitimados activos puede ser facilitada mediante diversas técnicas. Por un lado asociaciones que cumplan determinados requisitos pueden recibir subvenciones públicas para aplicarlas a su función social de defensa (también judicial) de determinados intereses ${ }^{173}$. Pero

168 El carácter en cierta medida altruista de esta actuación es lo que puede explicar que, en algunos supuestos, se establezcan "premios" para el actor: así PARADA CAICEDO, Informe Colombia y el art. 15 del borrador de Código Modelo de Procesos Colectivos para Iberoamérica.

169 Sengayen, "Poland", The Globalization of Class Actions, p. 43. Lupol, Italy Report (D.L. 4 luglio 2006, n. 233).

170 Merol, Informe Argentina

171 Amrani MekKı, Rapport France. El régimen es similar en España, Gutierrez de Cabiedes, P., "Group litigation in Spain", The Globalization of Class Actions, apartado 12. Un matiz limitativo distinto tiene la regulación de la que informa FILAtova, Russia Report.

172 Baetge, "Germany", The Globalization of Class Actions, p. 11; Amrani Mekkı, Rapport France. No obstante, hace notar SenGayen, "Poland", The Globalization of Class Actions, p. 48, que: "although speculative funding arrangements are prohibited, they have been known to be occurring between lawyers and clients in practice".

173 Informan de que no se conceden esas subvenciones Parada CaICEDo, Informe Colombia; Honma, Japan Report, LuPOI, Italy Report, FILATOVA, Russia Report. En sentido afirmativo, MEROI, Informe Argentina y BaEtGe, "Germany", The Globalization of Class Actions, p. 26. 
la técnica principal ${ }^{174}$ consiste en atribuir a determinados legitimados activos, mediante regla especial ventajosa ${ }^{175}$, el derecho a una gratuidad total o parcial de los costes de litigación. Así ocurre, con diverso alcance subjetivo, en varios ordenamientos ${ }^{176}$.

B) Expectativas de recuperación y riesgos de incremento de costes por el régimen de la condena en costas

La influencia en las opciones de litigación de la obligación inicial de pago de los gastos procesales propios depende, en definitiva, de lo que resulte del régimen legal de condena en costas.

El criterio más general es el del vencimiento (loser pays) ${ }^{177}$. La ley suele matizar ese criterio y permitir que el tribunal excluya justificadamente la imposición de costas al vencido, pero de esta potestad se hace uso excepcional ${ }^{178}$. Por otra parte, aunque la regla del vencimiento pudiera parecer neutra en cuanto a su influencia sobre la decisión de litigar -en efecto, tanto puede perjudicar al actor, cuanto beneficiarle-, de entrada frena la decisión de presentar la demanda. Para contrarrestar esa influencia, en algún ordenamiento ${ }^{179} y$ en propuestas de reforma, ${ }^{180}$ se opta por diferentes reglas de condena en costas: para el actor, la regla de la temeridad o mala fe; para el demandado, la del vencimiento.

\section{Efectividad de los regímenes de protección de intereses supraindividuales en el proceso civil}

Los informes nacionales no han ilustrado suficientemente sobre la efectividad de las regulaciones que acabamos de exponer. Tal vez sea porque han atendido

\footnotetext{
174 Hay otras, como la de un Fondo para la Defensa de los Derechos Colectivos y de Grupo, que se aplica en Colombia: PARADA CAICEDo, Informe Colombia.

175 En algunos ordenamientos sólo parecen aplicables las normas generales: AmRANı MeKkı, Rapport France; Honma, Japan Report.

176 Kulskı, Poland Report, Fllatova, Russia Report; Merol, Informe Argentina. En Derecho español, la ley concede la gratuidad directamente a las Asociaciones de Consumidores y Usuarios y a las asociaciones de utilidad pública que tengan como fin la promoción y defensa de los derechos de las personas con discapacidad.

177 Así, con pequeños matices, Merol, Informe Argentina, Amranı MeKkI, Rapport France, LuPOI, Italy Report, Sengayen, "Poland", The Globalization of Class Actions, p. 43. También rige el principio del vencimiento en Derecho español. Hay un matiz importante en Japón, HonmA, Japan Report: "there is a general principle in Japan to disallow the payments of attorney fees by the party who loses the case".

178 Parada CaICEDO, Informe Colombia, advierte que la excepción es regla.

179 Destacadamente el Derecho brasileño, sobre el que véase, Pellegrini Grinover, "Brazil and Iberoamerica", The Globalization of Class Actions, apartado 18; GIDI, Las acciones colectivas, pp. 39-40.

180 El art. 15 del borrador de Código Modelo de Procesos Colectivos para Iberoamérica establece ese régimen, aunque con responsabilidad agravada para el litigante de mala fe -sea actor o demandado.
} 
más a los aspectos jurídicos que a los sociológicos. Pero puede conjeturarse que los silencios se explican porque la aplicación práctica es poco destacable.

La información que, hace pocos años, reunió un conocido proyecto de investigación, ${ }^{181}$ revela, en síntesis, lo siguiente:

1) Suelen faltar estadísticas con datos precisos sobre los casos. ${ }^{182}$ Cuando hay datos, son difícilmente valorables, porque falta información sobre el número de personas afectadas o una comparación con las cifras globales de la litigiosidad civil. ${ }^{183}$

2) Predominan las apreciaciones: Unas son positivas para el tiempo presente $^{184}$ o en una perspectiva de futuro; ${ }^{185}$ pero otras destacan el nulo, o muy escaso, uso de las regulaciones consideradas. ${ }^{186}$

3) Es interesante la apreciación, a veces respaldada por algunas cifras, de que los legitimados más activos son las entidades públicas. ${ }^{187}$ Eso es relevante para valorar la combinación de sistemas de protección de la que trataremos enseguida.

\section{LA COMPLEMENTARIEDAD DE LA ACTUACIÓN DE LOS PODERES PÚBLICOS NO JUDICIALES Y DE LOS TRIBUNALES CIVILES PARA LA PROTECCIÓN DE INTERESES SUPRAINDIVIDUALES}

Los modelos de actuación del Derecho que protege intereses supraindividuales no funcionan de manera absolutamente separada -o Administraciones públicas o tribunales civiles- y con el único punto de contacto del control judicial de la actividad de la Administración ${ }^{188}$. En este apartado proponemos

181 Me refiero a The Globalization of Class Actions, varias veces citado en esta ponencia y del que forman parte los trabajos que se mencionan en las notas inmediatamente siguientes.

182 Reconocen la inexistencia de datos estadisticos: PellegrinI Grinover, "Brazil and Iberoamerica", apartado 19; Gutierrez de Cabiedes, "Spain", apartado 6. Extraen los datos de la información publicada en la prensa jurídica: Tzankova, I. N., Lunsingh Scheuleer, D. F., "Class Actions, Group litigation and Other Forms of Collective Litigation. Dutch Report", pp. 13-15. Aporta datos fragmentarios: Sengayen, "Poland", pp. 45-46.

183 Tzankova, Lunsingh Scheuleer, "Dutch Report", pp. 13-15; Baetge, "Germany", pp. 17-18.

184 Pellegrini Grinover, "Brazil and Iberoamerica", apartado 19; Gubbins, M., López, C., "Class Actions in Chile", p. 37.

185 Gutierrez de Cabiedes, "Spain", apartado 6.

186 Sugawara, "Japan", p. 6; Magnier, "France", pp. 14-15; Sousa Antunes, "Class Actions, Group litigation and Other Forms of Collective Litigation. Portuguese Report", p.20; Bernt-Hamre, "Class Actions, Group litigation and Other Forms of Collective Litigation in the Norwegian Courts", p.18.

187 Sengayen, "Poland", p. 45 (the President of the Office for the Protection of Competition and Consumers, regional consumer ombudsmen, prosecutors); Merol, Informe Argentina, (el Defensor del Pueblo); Pellegrini Grinover, "Brazil and Iberoamerica", apartado 19 (the General Attorney).

188 Véase el apartado III, 4.A.b y 4.B 
un acercamiento ${ }^{189}$ a diferentes manifestaciones de complementariedad entre la actuación de los poderes públicos no jurisdiccionales ${ }^{190}$ y la de los tribunales civiles.

1. Concurrencia de potestades sobre las mismas materias, pero para la producción de efectos jurídicos diferentes

La concurrencia de potestades (de la Administración, de los tribunales civiles) sobre la misma materia puede ser origen de ineficiencias de los sistemas de protección de los intereses jurídicos. El reto de la complementariedad consiste en regular los respectivos ejercicios de ambas potestades de manera que no sólo no se perturben recíprocamente, sino que incluso potencien su efectividad.

A) Las materias sobre las que hay concurrencia de potestades y los diferentes efectos jurídicos de éstas

Además de una remisión al apartado III. 1 y 3, Ilamo la atención sobre las materias destacadas en los informes nacionales: el Derecho de defensa de la competencia o antimonopolio ${ }^{191}$-excepto el régimen de la competencia desleal, cuya aplicación, salvo en algún supuesto, corresponde a los tribunales civiles_- ${ }^{192}$, el Derecho de protección de consumidores ${ }^{193}$, y el que regula la protección de los datos de carácter personal ${ }^{194}$.

En el ámbito de la Unión Europea tiene especial importancia la concurrencia que puede producirse por la reforma del sistema de aplicación de las normas sobre defensa de la competencia en el ámbito de la Unión (Reglamento 2003/1/ $\mathrm{CE}$, de 16 diciembre). Los tribunales tienen jurisdicción para aplicar directamente los arts. 81 y 82 Tratado CE (arts. 1, 3 y 6 Reglamento 1/2003) y esa atribución concurre con la que se hace a favor de las Administraciones públicas de la

\footnotetext{
${ }^{189}$ Utilizo esta expresión para indicar que la exposición será muy modesta, por los límites de extensión de esta ponencia y porque la información que he recibido no ha sido muy amplia.

190 Estos términos son más correctos, porque no siempre se trata de Administraciones públicas, pero sí, en todo caso, de entidades públicas que no tienen atribuida la potestad de juzgar, aunque su función esté muy próxima al ámbito de actividad de los tribunales de justicia-como es el caso del Ministerio Público-.

191 Honma, Japan Report, Merol, Informe Argentina; Kulskı, Poland Report; LupOI, Italy Report.

192 KULSKI, Poland Report. Ocurre algo similar en España, donde la atribución solo se hace a las autoridades administrativas de defensa de la competencia si las conductas desleales han afectado al interés público.

193 Honma, Japan Report, Merol, Informe Argentina; y en muchos otros ordenamientos.

194 LupOI, Italy Report.
} 
competencia. ${ }^{195}$ Pero, así como las últimas tienen poderes discrecionales para decidir si asumen el tratamiento de cierto asunto (véanse, p. ej., los arts. 5, 6, 49.3, 53.1 b Ley española de Defensa de la Competencia -en adelante, LDC-), los tribunales deben, en principio, admitir cualquier pretensión que se presente. Dependerá de normas nacionales -inexistentes, p. ej., en Derecho español-que puedan no admitir a trámite una demanda por la razón de que el proceso civil no sea idóneo para tratar la clase de asunto planteado.

Sobre los diferentes efectos jurídicos de ambas clases de potestades remito al apartado III.3. Puede haber coincidencia en cuanto al efecto jurídico de ordenar la cesación de conductas ilícitas ${ }^{196}$, pero, así como las potestades de autorización de actividades y de inspección sólo están atribuidas a las Administraciones públicas, las de emitir declaraciones sobre la validez de contratos y de condenar al pago de indemnizaciones por daños están, con alguna rara excepción ${ }^{197}$, reservadas a los tribunales de justicia ${ }^{198}$.

B) La articulación -o los problemas de articulación- del ejercicio de las potestades concurrentes

Aunque producen diferente efectos jurídicos, las potestades administrativas y judiciales pueden coincidir en la constatación de los hechos relevantes y en la apreciación de la ilicitud de los mismos. Un razonable objetivo de coherencia aconseja establecer normas que posibiliten coordinar su ejercicio.

a) Suspensión del proceso judicial por la pendencia del procedimiento administrativo o viceversa

En cuanto a la suspensión de un proceso civil cuyo objeto coincida, total o parcialmente, con la conducta infractora que sea objeto de un procedimiento

195 En Derecho español se dictó una nueva Ley de Defensa de la Competencia y se reformaron otras leyes para ajustarlas al Reglamento 1/2003, también para los asuntos de ámbito territorial sólo nacional (arts. 1 y 2 y disposición adicional primera de la Ley de Defensa de la Competencia de 2007 -en adelante: LDC- y art. 86ter.2 de la Ley Orgánica del Poder Judicial).

196 Especialmente desde que se ha establecido ampliamente la acción judicial de cesación. No obstante, pueden subsistir las diferencias en cuanto a la intensidad coercitiva que acompaña a las potestades de las Administraciones públicas de competencia y a las de los tribunales, más rigurosas las primeras que las segundas, al menos en Derecho español.

197 Parada Caicedo, Informe Colombia: en competencia desleal, si la Superintendencia de Industria y Comercio actúa primero, desplaza a la justicia ordinaria. Merol, Informe Argentina: "En cuanto a ordenar indemnizaciones a favor de los perjudicados por la conducta infractora, la reforma de la Ley de Defensa del Consumidor introdujo la posibilidad de que la autoridad de aplicación condene al proveedor al pago del "daño directo" ocasionado (...) Los autores se dividen en cuanto a la constitucionalidad de esta norma".

198 Filatova, Russia Report; Amrani Mekki, Rapport France; Lupol, Italy Report. En Derecho europeo de la competencia -como en Derecho español- las potestades de las administraciones públicas pueden dar lugar a diversos y muy potentes efectos jurídicos (arts. 5 y 7 Reglamento 1/2003; arts. 53, 61-67 LDC), pero entre los mismos no se incluyen los mencionados en el texto. Otro ejemplo de lo mismo, en Derecho español, en el art. 19 de la Ley de Protección de Datos. 
administrativo en curso, hay normas que directamente la imponen ${ }^{199}$, pero es más común que no exista una norma de suspensión ${ }^{200}$, o que las normas confieran al tribunal un ámbito de apreciación para decidir sobre la suspensión ${ }^{201}$.

La admisión de una demanda por los tribunales civiles no impide la iniciación de un procedimiento administrativo sobre el mismo caso, ni suspende el iniciado. La razón es, sin duda, el interés público perseguido por la actuación administrativa, que requiere una atención inmediata. Este efecto sólo se produce en determinados casos de prejudicialidad penal (p. ej., art. 46 LDC) y para la actuación de las Administraciones públicas de nivel estatal, no para la Administración de la Unión Europea.

b) Acceso en el proceso civil a las pruebas en poder de la Administración pública

Este punto de coordinación tiene enorme interés práctico por la extrema dificultad de preparar privadamente un conjunto de medios de prueba que, por el contrario, podrían hallarse en poder de la Administración pública, como resultado del ejercicio de sus funciones en la materia.

Hay ordenamientos en que el acceso a esa prueba está restringido y se práctica escasamente ${ }^{202}$. En otros rige ordinariamente ${ }^{203}$, e incluso se han hecho reformas recientes para facilitarlo ${ }^{204}$.

En el ámbito del Derecho europeo de la competencia está previsto por el art. 15 Reglamento 1/2003, y, además, sin necesidad de solicitud del tribunal, que la Comisión pueda aportar información. Para los asuntos de ámbito exclusivamente nacional, el Derecho español establece un régimen similar (arts. 16 LDC, 15 Ley Procesal Civil), aunque se excluye la aportación de datos o documentos obtenidos en el ámbito de "programas de clemencia".

199 LuPOI, Italy Report. En Derecho europeo de la competencia, del art. 35.3 en relación con el art. 11.6 Reglamento $1 / 2003$, se deduce que los tribunales quedarán privados de competencia para conocer de procedimientos judiciales sobre pretensiones diferentes a las de condena a indemnización (p. ej., cesación y otros efectos instrumentales).

200 Filatova, Russia Report; Amrani Mekki, Rapport France.

201 Así, en cuanto a la aplicación del Derecho europeo de la Competencia, el art. 16.1 Reglamento 1/2003 tiene un objeto más amplio que los preceptos que imponen imperativamente la suspensión, pero encomienda al tribunal la decisión de suspender cualquier procedimiento. Kulski, Poland Report; Lupoi, Italy Report. En Derecho español, el art. 42.3 de la Ley Procesal Civil autoriza al tribunal a suspender el proceso en atención a la pendencia de un procedimiento administrativo; específicamente, el art. 434 de la misma ley le autoriza a suspender el plazo para dictar sentencia si considera necesario conocer el pronunciamiento de una autoridad administrativa de la competencia.

202 Filatova, Russia Report.

${ }^{203}$ Meroi, Informe Argentina.

${ }^{204}$ Honma, Japan Report. 
c) Eficacia de las resoluciones de las Administraciones públicas respecto de las sentencias de los tribunales

¿Han de tener una eficacia jurídicamente vinculante en alguna medida, o un valor probatorio privilegiado, o el tribunal será libre para apreciar el valor probatorio de las constataciones de hecho de la autoridad administrativa y para aceptar las valoraciones jurídicas que la misma hubiera emitido?

Junto a respuestas negativas a una vinculación ${ }^{205}$, hay aproximaciones a una respuesta afirmativa ${ }^{206}$, y otras claramente afirmativas ${ }^{207}$. Hay, también, normas ambiguas, diseñadas para que los tribunales presten especial atención a resoluciones administrativas, pero que omiten regular la incidencia de estas resoluciones en la sentencia del tribunal ${ }^{208}$. En mi opinión, en este punto de coordinación, se confía en que los tribunales, de hecho y en atención a la fiabilidad de la especialización de la Administración que hubiera decidido, se inclinen por aceptar los contenidos de las resoluciones administrativas en lo relevante para la sentencia sobre el asunto litigioso ${ }^{209}$.

\section{Actuación de las entidades públicas en el proceso civil}

Una segunda forma de complementariedad consiste en que una entidad pública pueda presentar la posición que estime adecuada al interés público ante el tribunal civil, de modo que pueda influir en la resolución sobre la tutela judicial de los intereses supraindividuales.

A) Atribución de legitimación activa a entidades públicas

En este supuesto la entidad pública no sólo es parte procesal, sino que también puede proponer una pretensión de tutela judicial.

\footnotetext{
205 Filatova, Russia Report; Honma, Japan Report.

206 Meroi, Informe Argentina. En los trabajos de la UNCTAD, Model Law on Competition, p. 8, se apunta la posible "Treatment of the administrative (...) finding or illegality as prima facie evidence of liability in all damage actions by injured persons".

207 Así la vinculación establecida por el art. 16.1 Reglamento 1/2003: "When national courts rule on agreements, decisions or practices under Article 81 or Article 82 of the Treaty which are already the subject of a Commission decision, they cannot take decisions running counter to the decision adopted by the Commission".

208 P. ej., art. 271 de la Ley española Procesal Civil, que establece un plazo completamente excepcional para que resoluciones administrativas "condicionantes o decisivas" para la sentencia, puedan ser aportadas al proceso; y el art. 434 de la misma ley, que autoriza a suspender el proceso civil en caso de que "resulte necesario conocer el pronunciamiento" de una autoridad administrativa de defensa de la competencia.

209 Puede, por esta razón, comprenderse la estrategia procesal a la que se refiere Amrani Mekki, Rapport France: "les plaignants attendent souvent que les autorités administratives statuent sur un différend avant d'engager des poursuites au civil ».
} 
En algunos ordenamientos y en los procesos no penales, las entidades públicas, específicamente el Ministerio Público, sólo tienen esta atribución en los supuestos más tradicionales (estado civil, defensa de personas en situación de desamparo ${ }^{210}$; en cualquier caso no en los supuestos que aquí venimos considerando ${ }^{211}$.

Por otra parte, debe reseñarse un fenómeno nuevo: el Ministerio Público ya no es el único ente público al que se atribuye la defensa de los intereses sociales y públicos ante los tribunales; otras entidades públicas -a veces las mismas que tienen competencias administrativas en la materia litigiosa-, pueden presentar demandas. La explicación sería la principal dedicación del Ministerio Público al proceso penal ${ }^{212}$, sin embargo en algunos ordenamientos el Ministerio Público ha resultado ser el más activo en la defensa de intereses supraindividuales ${ }^{213}$.

Las materias y clases de tutela para las que las entidades públicas reciben legitimación activa, tienen diferente amplitud. Unos ordenamientos atribuyen esta legitimación con un alcance general para la tutela de intereses supraindividuales -incluyendo los individuales homogéneos- o con un alcance muy amplio ${ }^{214} 215$. Otros ordenamientos acotan la atribución a supuestos especiales ${ }^{216}$.

\footnotetext{
210 Honma, Japan Report; Amrani Mekki, Rapport France ; Orfanidis, Griechenland Bericht; Filatova, Russia Report.

211 Este dato puede ser comprobado precisamente por la falta de referencias a esta atribución de legitimación activa en los supuestos que veremos a continuación en el texto.

212 Meroi, Informe Argentina.

213 Gidi, A., "La legitimación para demandar en las acciones colectivas", en La tutela de los derechos difusos, colectivos e individuales homogéneos. Hacia un Código Modelo para Iberoamérica, Gidi, Ferrer Mac-Gregor (coord.), Editorial Porrúa, 2004, pp. 88-89.

214 Así, en Brasil, el art. 5 de la Lei de Ação Civil Pública y el art. 82 del Código do Consumidor; sobre los mismos, Pellegrini Grinover, "Brazil and Iberoamerica", The Globalization of Class Actions, apartado 7, y Gidi, Las acciones colectivas, pp. 72-73. Para Colombia, los arts. 12 y 48 de la Ley 472, de agosto 5 de 1998, que desarrolla el art. 88 de la Constitución en relación con el ejercicio de las acciones populares y de grupo. Y el art. 3 del borrador de un Código Modelo de Procesos Colectivos para Iberoamérica.
}

${ }^{215}$ El Derecho polaco merece una mención especial: Kulski, Poland Report; Sengayen, "Poland", The Globalization of Class Actions, pp. 24-26, 28-29.

216 P. ej., en Derecho español se atribuye legitimación activa a:1) El Ministerio Publico, el Instituto Nacional de Consumo y entidades asimiladas a ésta, en materia de protección a consumidores, para la defensa de sus intereses colectivos y difusos, y para pretender la cesación de conductas lesivas. 2) El Ministerio Público, el Instituto Nacional del Consumo y entidades asimiladas a ésta, para la defensa de intereses de carácter colectivo afectados en materia de condiciones generales de la contratación, de competencia desleal y de publicidad ilícita. Esta legitimación no alcanza a pretender la tutela de derechos individuales homogéneos. 3) Respecto de derechos supraindividuales en materia laboral, el Ministerio Público (para impugnar convenios colectivos y estatutos de sindicatos y de asociaciones empresariales) y la autoridad administrativa laboral (en supuestos legales determinados). 4) Organismos públicos competentes para defender los intereses de personas afectadas indeterminadas o de difícil determinación en caso de lesión del derecho de igualdad de trato entre hombre y mujeres. Específica- 
Para valorar esta atribución de legitimación es relevante observar si la misma es estrictamente concurrente con otras legitimaciones activas ${ }^{217}$, o tiene carácter subsidiario respecto de las mismas. Mientras algunos ordenamientos guardan silencio, otros enfatizan el carácter concurrente ${ }^{218}$. Esto no excluye cierta subsidiariedad, pero revela que la misma responde a una situación de hecho o social -inactividad de otros legitimados por carencias organizativas o de financiación- ${ }^{219}$ y no a un imperativo jurídico ${ }^{220}$.

Por fin, es también un dato a considerar en la valoración de esta legitimación, caso de que la misma permita formular pretensiones de tutela de derechos o intereses individuales homogéneos, si la actuación procesal de la entidad pública está subordinada a (o condicionada por) la decisión de los afectados, expresada positivamente como autorización o como omisión de manifestar una separación de la acción ejercitada.

B) Atribución de legitimación pasiva, de facultad de intervención procesal o menos

Puede haber normas que establezcan que la entidad pública (el Ministerio Público) deba ser parte en un proceso, aunque carezca de legitimación activa. En tal caso no podrá introducir una pretensión de tutela judicial, pero -sin el riesgo de quedar sujeto a limitaciones que, en algunos ordenamientos, afectan a la intervención procesal- tendrá todas las demás facultades propias de una parte procesal.

El ordenamiento puede optar por atribuir a la entidad pública una facultad de intervención en el proceso. En tal caso, la intensidad de su influencia dependerá del régimen de la intervención, específicamente de que las facultades de alegar hechos, de proponer pruebas e intervenir en su práctica y de recurrir resoluciones se subordinen poco o mucho a la actuación procesal de las partes principales.

Por fin, entiendo que hay una tercera forma en la que una entidad pública puede presentar su posición ante el tribunal civil. Se trata de la atribución a esa entidad de facultades aisladas, singulares, de actuación procesal, pero no en ca-

mente, la Delegación Especial del Gobierno contra la Violencia sobre la Mujer, el Instituto de la Mujer y entidades asimiladas pueden pretender condena a cesación de publicidad ilícita por vejatoria de la imagen de la mujer o discriminatoria de la misma.

217 Véanse los supuestos en el apartado IV.2.

218 Art. 82 del brasileño Código do Consumidor; sobre el tema, Pellegrini Grinover, "Brazil and Iberoamerica", The Globalization of Class Actions, apartado 7. En el mismo sentido, el art. 3 del borrador de Código Modelo de Procesos Colectivos para Iberoamérica.

219 Gidi, "La legitimación para demandar en las acciones colectivas", pp. 108-109.

${ }^{220}$ Este imperativo aparece cuando se dispone que, en caso de renuncia o desistimiento injustificado de otro legitimado, el Ministerio Público debe continuar la acción (art. 5 de la brasileña Lei de Ação Civil Pública). 
lidad de parte, ni de interviniente. Es paradigmático, en este aspecto, el régimen establecido, en Derecho europeo de la Competencia, por el art. 15, apartados 3 y 4 del Reglamento 1/2003. Así como el apartado 4 permite entender que los ordenamientos nacionales puede atribuir a las autoridades de competencia (comunitarias o nacionales) calidad de parte o facultad de intervención en el proceso, el apartado 3 se limita a garantizar a esas autoridades el conocimiento de las actuaciones procesales y la facultad de presentar observaciones escritas u orales ante el tribunal. ${ }^{221}$ La eficacia de las observaciones presentadas consiste, en mi opinión -y dado que no se trata de alegaciones de parte o de un interviniente-, en facilitarle al tribunal que ejerza con mayor calidad los poderes de oficio que el ordenamiento le atribuye.

\section{ReFLEXIONES FINALES}

Concluyo con unas reflexiones sobre los resultados obtenidos, aunque lamento que el espacio disponible no me permita desarrollar una fundamentación más completa.

1. Unos apuntes sobre terminología y realidad (jurídica): ¿Private enforcement vs public enforcement o judicial enforcement vs administrative enforcement?

El lenguaje es el vehículo de expresión del Derecho y de la ciencia jurídica. Cuando una terminología jurídica es utilizada en su contexto sociocultural, las reflexiones sobre el significado de aquélla no suelen ser necesarias. No obstante, este Congreso -como advierte su propio lema: "La justicia procesal en un mundo globalizado" - extiende su atención a contextos muy diversos. Eso impone una breve meditación sobre el significado de la expresión private enforcement y un intento de, como mínimo, esbozar las diversas modalidades de enforcement del Derecho, en atención a sus características reales, no sólo a sus nombres.

En el contexto del Derecho de los USA, private enforcement significa la iniciativa privada ante los tribunales para pedir la protección de los derechos privados lesionados, lo que, al mismo tiempo, puede entenderse -por lo menos en algunas clases de casos- como un modo de producir que el orden jurídico sea concretamente respetado, lo que satisface el interés general222.

221 El Derecho interno español (arts. 16 LCD y 15 bis de la Ley Procesal Civil) añade a la facultad de presentar observaciones, la de "aportar información". Ésta puede entenderse como una facultad nueva, relativa a la introducción de pruebas en soporte documental, aunque no hubieran sido acordadas por el tribunal, ni a instancia de parte, ni de oficio.

222 Hess, "Private law enforcement", p. 67; Gerber, D. J., "Private enforcement of competition law: a comparative perspective", en Möllers, Heinemann, Eds., The Enforcement of Competition Law, pp. 434, 437; entre otros muchos que después se mencionarán. 
Es Ilamativo que la expresión haya llegado a adquirir ese significado prioritario, porque, propiamente, el enforcement no es privado -en el sentido de que no es autotutela, no es actuación del Derecho por el propio poder, individual o colectivo, de un particular o de un grupo de particulares-, sino judicial, aunque la actividad del tribunal dependa de -y esté acotada por- la iniciativa de los particulares.

También en Derecho estadounidense, public enforcement significa tanto que una entidad pública tiene poder de iniciativa para instar la aplicación del Derecho por los tribunales ${ }^{223}$, como que una agencia gubernamental tiene poder de aplicar el Derecho, sin perjuicio de posterior revisión judicial ${ }^{224}$. Estos dos significados de public enforcement son, también, los predominantes entre los teóricos del análisis económico del Derecho ${ }^{225}$.

En esta última expresión están más cerca el significante y el significado. No obstante, en ambos hay una imprecisión importante, porque no es lo mismo tener el poder de iniciativa para el enforcement que el poder para realizar el enforcement. Además, este último poder puede ser en sí mismo diferente.

En el contexto europeo, el significado de private enforcement va unido al judicial enforcement, pero se contrapone al administrative enforcement, en el que un agente del poder público no judicial tiene atribuido el poder de aplicación del Derecho ${ }^{226}$. Por esa razón, aunque la expresión private enforcement también ha hecho fortuna para significar el acceso directo de los particulares a los tribunales para instar la aplicación del Derecho de la competencia y de otros sectores del Derecho ${ }^{227}$, la distinción importante se establece entre el en-

223 Gerber, "Private enforcement of competition law", pp. 434-436, 438.

224 Gerber, "Private enforcement of competition law", p. 438. Véase, sin embargo, Hodges, "Competition Enforcement", p. 1394.

225 Polinsky, A. M., Shavell, S., "The theory of public enforcement of law", pp. 405-406, in Handbook of Law and Economics, Volume 1, Edited by A. Mitchell Polinsky and Steven Shavell (C) 2007 Elsevier B.V. Available at http://www.sciencedirect.com. Jackson, H. E., Roe, M. J., "Public and Private Enforcement of Securities Laws: Resource-Based Evidence", (March 16, 2009). Journal of Financial Economics (JFE), Vol. 93, 2009; Harvard Public Law Working Paper No. 0-28; Harvard Law and Economics Discussion Paper No. 638. Available at SSRN: http://ssrn.com/abstract=1000086. Klöhn, L., "Private versus public enforcement of laws - a Law \& Economics perspective", paper presented at the Conference "Compensation of Private Losses - The Evolution of Torts in the European Business Law" on November 25, 2010 in Münster, Germany. Electronic copy available at: http://ssrn.com/abstract=1730308.

226 Gerber, "Private enforcement of competition law", pp. 442-445; Salerno, "The Competition Lawization of Enforcement", pp. 1-7; Eger, Weise, "Limits to the private enforcement of antitrust law", apartados I a III.

227 Salerno, "The Competition Law-ization of Enforcement", pp. 1-7; Eger, Weise, "Limits to the private enforcement of antitrust law", apartados I a III; Alfaro, "Contra la armonización positiva". 
forcement por las autoridades administrativas -sin perjuicio de posterior revisión judicial-y el enforcement por los tribunales ${ }^{228}$.

Ahora bien, en este último contexto, también aparece la otra perspectiva de diferenciación entre lo privado y lo público, cuando se atiende a esas cualidades en las entidades que tienen el poder de iniciativa para requerir el enforcement ante los tribunales ${ }^{229}$.

Resulta, pues, que la incidencia de lo privado y lo público debe ser considerada en dos diferentes componentes del sistema de enforcement: El titular del poder de realizar el enforcement y el titular del poder de requerir el judicial enforcement-prescindimos de examinar la puesta en marcha del administrative enforcement-.

Las cuestiones constitucionales respecto de cada una de esas piezas del sistema de enforcement son diferentes. El distinto diseño de las mismas conduce, también, a distintas apreciaciones sobre su efectividad y eficiencia.

\section{Los marcos constitucionales del Law enforcement}

El primer parámetro de la ordenación del Law enforcement es normativo y, específicamente, constitucional. No en el sentido de una constitución formal y escrita, pero sí en el de que es un tema que se halla en el ámbito de las opciones político-jurídicas fundamentales de un ordenamiento. Por esa misma razón, es un parámetro diversificado según las sociedades políticamente organizadas. Desde este parámetro constitucional han de considerarse dos grupos de grandes cuestiones, a los que tal vez deba añadirse un tercero.

A) La amplitud del poder de resolución de controversias por la Administración pública, la potestad de juzgar y la norma de atribución de esta potestad

Las opciones sobre el poder de enforcementy su atribución están enmarcadas por las decisiones constitucionales sobre los temas sintetizados en el epígrafe. La síntesis podría ser mayor, porque la cuestión radical es la respectiva determinación del poder que debe ser atribuido a los tribunales y del que debe estar encomendado a la Administración pública.

\footnotetext{
228 White Paper on Damages ...EC antitrust rules, 1.2; Communication from the Commission to the European Parliament and the Council. Report on the functioning of Regulation 1/2003, 1 and 6; Hodges, "Competition Enforcement", p. 1394. La distinción ya está destacada en la terminología, por ejemplo, en Cafaggi, Micklitz, "Administrative and Judicial Collective Enforcement"; los mismos autores la desarrollan en el apartado 1 del artículo, así como en el capítulo "Administrative and judicial enforcement in consumer protection: The way forward", en Cafaggi, Micklitz, Eds., New Frontiers of Consumers Protection. The Interplay between Private and Public Enforcement.

229 Cafaggi, Micklitz, "Administrative and Judicial Collective Enforcement", apartado 5; Cafaggi, Micklitz, "Administrative and judicial enforcement in consumer protection", pp. 406-407; Hodges, Ch., The reform of Class and Representative Actions in European Legal Systems. A New Framework for Collective Redress in Europe, Hard Publishing, Oxford, Portland, 2008, pp. 20-23, 29-35.
} 
Las respuestas no son fáciles ${ }^{230}$. Y lo son menos aún si se tiene presente que dependen de los marcos constitucionales, y estos no sólo pueden delimitar de manera diferente esas atribuciones, sino dedicar a esa delimitación una atención desigual. Pueden considerarse las siguientes referencias a título de ejemplo:

1) La Constitución española de 1978 dispone la creación de una única organización judicial, regula los principales requisitos de los jueces y tribunales que la componen, establece taxativamente las excepciones a la regla general enunciada al principio, atribuye en exclusiva a esos tribunales la potestad jurisdiccional e incluso regula, en alguna medida, en qué consiste esta potestad ${ }^{231}$.

2) La Grundgesetz alemana encomienda a los jueces el rechtsprechende Gewalt (art. 92), establece los requisitos básicos que deben cumplir jueces y tribunales (arts. 97 y 98), aunque la estructura federal conduce a dejar abiertos diversos aspectos de las organizaciones judiciales. Contiene normas que especifican qué decisiones están reservadas a la potestad jurisdiccional, pero la norma más general y amplia sobre ello es la del art. 19 (4), que reconoce el derecho a acudir a los tribunales ante cualquier lesión de derechos por el poder público, lo que presupone que éste puede haber resuelto previamente, incluso con habilitación legal.

3) Es paradigmática la consideración de la jurisprudencia del Tribunal Europeo de Derechos Humanos sobre el art. 6 del Convenio Europeo de Derechos Humanos. Para aplicar las garantías de este artículo el Tribunal ha necesitado elaborar nociones autónomas de "tribunal", "materia penal" y "litigios sobre obligaciones y derechos de carácter civil", con el fin de evitar verse limitado por las diferentes calificaciones formales de los distintos ordenamientos ${ }^{232}$.

Atendida esa pluralidad de marcos constitucionales, es posible que, en algunos de ellos, entidades de las Administraciones públicas dependientes del Poder Ejecutivo tengan atribuidos poderes de enforcement con arreglo a un modelo de autotutela administrativa ${ }^{233}$. Si es así, la Administración pública está investida, en primer lugar, de poderes de regulación, que vinculan a determinadas

${ }^{230}$ Véase la reciente exposición de Cadiet, L., Normand, J., Amrani Mekki, S., Théorie Générale du procès, PUF, Paris, 2010, pp. 396-499.

${ }^{231}$ Una síntesis útil en Ortells Ramos, M., et alt., Introducción al Derecho Procesal, Aranzadi-Thomson Reuters, Cizur Menor (Pamplona), 2010, pp. 57-135.

${ }^{232}$ Cadiet, Normand, Amrani Mekki, Théorie Générale, pp. 399, 406; Ortells Ramos, M., "Jurisprudencia del TEDH sobre el art. 6 del CEDH en el proceso penal (La doctrina de la "noción autónoma de materia penal". derechos a un tribunal independiente e imparcial y a que la causa sea oída equitativamente. Presunción de inocencia)", en La jurisprudencia del Tribunal Europeo de Derecho Humanos, Consejo General del Poder Judicial, Madrid, 1993, pp. 175-213.

${ }^{233}$ Sobre este modelo, con un enfoque que excede del Derecho español, García de Enterría, E., "Las relaciones entre Administración y Justicia y el principio de autotutela", en García de Enterría, E., Fernández, T-R, Curso de Derecho Administrativo, Civitas, Madrid, 2002, pp. 491-521. 
personas, $y$, sobre esa base y en segundo lugar, en caso de incumplimiento de quienes se hallan sujetos a tales poderes, está también habilitada para ejercer correlativos poderes de enforcement, de modo que su función como regulador es más efectiva que si debiera acudir a los tribunales para reaccionar ante los incumplimientos.

Este modelo de atribución del poder de enforcement no contradice la reserva constitucional de la potestad jurisdiccional a los tribunales, porque la Administración actúa en una relación propia, que ha devenido controvertida por la conducta de incumplimiento de quienes se hallan sujetos a los poderes de regulación. No actúa como un juez, como un tercero ajeno a la relación -ahora litigiosa- entre otras personas ${ }^{234}$.

Pero los modelos pueden, incluso, no ser tan nítidos como el descrito. Concretamente es posible que la práctica constitucional conduzca:

1) A un deslizamiento del modo de concebir la potestad jurisdiccional que, de ser entendida como la potestad de aplicar el Derecho para resolver controversias entre personas ajenas al que tiene el poder de resolución, tienda hacia la idea de un poder de revisión de resoluciones previas de una entidad que no tenga la calidad de tribunal ${ }^{235}$.

2) A la creación de entidades públicas, dotadas de poderes de enforcement, que, por sus características organizativas (principalmente, independencia respecto del Poder Ejecutivo), estén a mitad de camino entre los tribunales y las entidades netamente administrativas. Esta opción organizativa contribuye a legitimar fenómenos como el que se acaba de describir, y resulta muy facilitada en aquellos ordenamientos en los que, salvo el establecimiento del requisito de la independencia y de otros próximos al mismo, existe una carencia de claridad formal en la definición de las entidades que tienen la calidad de tribunales.

En un marco constitucional que lo permita, se puede llegar a establecer el administrative enforcement en algunos sectores del Derecho, por dos razones:

1) Principalmente, y ésta es una condición imprescindible, porque una apreciación política -que sólo considero aceptable si está democráticamente legitimada- estima que el interés público o un interés social justifican la in-

\footnotetext{
${ }^{234}$ Reproduzco una interesante cita de Bettermann que recoge Dütz, W., Rechtsstaatlicher Gerichtsschutz im Privatrecht, Berlin-Zürich, 1970, p. 202: "Bestehe der Rechtsstreit dagegen zwischen dem Bürger und der Verwaltung, so sei deren Streitentscheidung keine Rechtsprechung und kollidiere daher nicht mit der Rechtsprechunsmonopole der Gerichte".

235 Sobre los abusos de la autotutela administrativa, García de Enterría, "Las relaciones entre Administración y Justicia y el principio de autotutela", pp. 522-524 y bibliografía citada en p. 538. Sobre el deslizamiento apuntado en el texto en la práctica constitucional española, Ortells Ramos, M., Prólogo a la monografía de Bellido Penadés, R., La tutela frente a la competencia desleal en el proceso civil, Comares, Granada, 1998, pp. XXI-XXIV.
} 
tervención o una actuación regulatoria de la Administración pública en cierto ámbito de las relaciones sociales.

2) Presupuesto lo anterior, la siguiente razón es que la efectividad de esa opción política podría perderse o minimizarse si, en caso de incumplimiento de las resoluciones de regulación, la Administración pública tuviera que instar, como un particular, el judicial enforcement.

Ahora bien, el marco constitucional también impone:

1) El respeto a la reserva de la potestad jurisdiccional a los tribunales. Pienso que ésta es la razón que, en las materias que hemos tratado en el apartado II de la ponencia, constituye obstáculo insuperable a que los poderes de enforcement -complementarios de poderes regulatorios de las Administraciones públicasalcancen hasta autorizar a éstas para hacer declaraciones sobre la validez y eficacia de contratos entre particulares y para imponer indemnizaciones por daños que estos hubieran sufrido. Así como las órdenes de cesación -reforzadas con sanciones- y las de restitución de las cosas al estado anterior a una infracción continúan siendo una respuesta ajustada al interés general o de un grupo social, cuya protección este atribuida al poder público, la declaración y la imposición mencionadas más arriba se referirían a relaciones entre particulares, entre terceros respecto de la Administración, de modo que ésta no podría invocar una potestad de autotutela, sino que estaría asumiendo, inconstitucionalmente, la potestad jurisdiccional.

2) El diseño legal de un control jurisdiccional posterior que en verdad sea pleno, de modo que el ejercicio diferido de la potestad de juzgar no se convierta en una pérdida de la esencia de esa potestad ${ }^{236}$.

3) La protección de los derechos fundamentales y, especialmente en esta materia, del derecho a la tutela judicial, que debe ser efectiva a pesar de que sólo pueda ser pretendida ante los tribunales después de que la Administración pública haya resuelto y, tal vez, hasta incoado el cumplimiento de su decisión ${ }^{237}$.

236 El debate sobre el alcance del poder de revisión jurisdiccional de la actividad administrativa es amplio y profundo. En la literatura jurídica española, pero con frecuentes referencias a doctrina de otros países y al Derecho comparado: García de Enterría, E., La lucha contra las inmunidades del poder, Madrid, 1979; Parejo Alfonso, L., Administrar y juzgar: dos funciones constitucionales distintas y complementarias, Madrid, 1993; Fernández Rodríguez, T. R., De la arbitrariedad de la Administración, Madrid, 1994; Sánchez Morón, M., Discrecionalidad administrativa y control judicial, Madrid, 1994; Beltrán de Felipe, M., Discrecionalidad administrativa y Constitución, Madrid, 1995; Desdentado Daroca, E., Los problemas del control judicial de la discrecionalidad técnica (Un estudio crítico de la jurisprudencia), Madrid, 1997; García de Enterría, E., Democracia, jueces y control de la Administración, Madrid, 1997.

${ }^{237}$ Principalmente eso debe conducir a un régimen adecuado de la tutela provisional en el proceso de control judicial. Remito a las diversas aportaciones de un ilustre administrativista español, que atienden también a planteamientos de Derecho comparado y analizan la incidencia que tuvo en esta materia 
B) La "legitimidad" de la legitimación y la efectividad del derecho a defender ante el tribunal el interés jurídico propio

La petición de protección judicial de un derecho o interés jurídico genera, por una parte, la expectativa de obtener diversos resultados favorables, pero, simultáneamente, abre también perspectivas de resultados desfavorables -principalmente, la pérdida, debida a la cosa juzgada que se producirá, de toda opción de obtener otra sentencia sobre lo mismo; también la imposición de obligaciones y responsabilidades por la actividad procesal (costas propias y, en ciertos supuestos, de la parte contraria)-. Además esos eventuales y dispares resultados dependen, en cierta medida, de la actividad, de la inactividad, y de los grados de acierto en una y en otra, de quien ha presentado la demanda o actúa como parte en el proceso.

Lo anterior justifica que la cualidad requerida para poder instar (con posible éxito) la tutela judicial respecto de un derecho o interés jurídico concreto se haga coincidir con la titularidad (de momento, simplemente afirmada) de los mismos. $Y$ esa coincidencia ha de producirse tanto positiva, como negativamente:

1) El titular del derecho o interés jurídico ha de poder pedir su protección judicial, si existe necesidad de la misma.

2) Nadie, sin el concurso de la voluntad de ese titular, ha de poder instar la tutela, porque, de ser así, el titular quedaría expuesto a resultados eventualmente desfavorables, con privación del poder de influir en la obtención de los mismos.

Dado que los intereses jurídicos tienen un diferente alcance subjetivo, la verificación de la coincidencia apuntada debe conducir a que se establezca una correlación entre el alcance subjetivo del interés, determinante de su titularidad, y la atribución del poder de instar su tutela judicial -quién tiene ese poder y qué tutela puede obtener, principalmente en cuanto a la extensión subjetiva de los efectos de la misma-. Como regla general esa exigible correlación impone que:

1) Si está en juego un derecho o interés propios de una persona física o de una persona jurídica privada, sólo ella puede pretender y obtener la tutela y, en todo caso, una sentencia que sólo a ella le afectaría ${ }^{238}$.

la sentencia "Factortame" del Tribunal de Justicia de las Comunidades Europeas: García de Enterría, E., La batalla por las medidas cautelares, Madrid, 1992.

${ }^{238}$ Las normas sobre derechos básicos, o fundamentales, ante los tribunales - que son el marco constitucional de esta materia- se refieren normalmente a las personas titulares de derechos individuales y expresan aquella requerida vinculación entre la persona y su derecho con expresiones tales como que esa persona debe ser oída por un tribunal para la "determinación de sus derechos y obligaciones" (art. 10 Declaración Universal de Derechos Humanos; art. 14 Pacto Internacional de Derechos Civiles y Políticos; art. 6 Convenio Europeo de Derechos Humanos; art. 8 Convención Americana de Derechos Humanos), o como que "tiene derecho a que su causa sea oída" para hacer esa determinación (art. 
2) En casos de interés colectivo o social de diferente extensión subjetiva, e, incluso, con distinta dificultad para precisar esa extensión, el poder de instar el enforcement, con alcance subjetivo a todos los partícipes en esos intereses, debe ser atribuido a un grupo de interesados, formalmente constituido o informal, pero legítimamente representativo de los mismos.

3) El interés general o público en una sociedad democrática corresponde a los ciudadanos o, más genéricamente, a los componentes de esa sociedad, pero estos manifiestan y ejercen su titularidad a través de instituciones públicas representativas, a las que también se debe atribuir -si no estuvieran investidas de un poder de administrative enforcement- el poder de instar el judicial enforcement.

El concurso de la voluntad del titular del derecho o interés es, en realidad, el elemento clave: esa expresión de voluntad significa tanto que quiere obtener la tutela (aspecto positivo), como que está dispuesto a asumir los riesgos del procedimiento para, eventualmente, conseguirla (aspecto negativo).

Sin embargo, pueden darse diversas situaciones que justifiquen excepciones o matices a aquella regla general. Consideremos las más importantes:

1) La lesión de intereses públicos y/o sociales puede concurrir con la lesión de una serie de intereses individuales, cuyos titulares pueden estar identificados o no ${ }^{239}$. Incluso si la acción judicial de los legitimados para defender el interés público y/o social limita sus principales efectos a los que son adecuados para la protección de tales intereses (declaración de ilicitud de las conductas, órdenes de cesación y restitución del estado anterior -salvo en cuanto a las relaciones entre particulares-): ¿Se deberá considerar contrario al marco constitucional que esa acción produzca un efecto parcial -prejudicial (favorable o desfavorable)- respecto de las acciones en defensa de los intereses individuales? Sin duda esa contrariedad no existiría si los titulares de los intereses individuales hubieran sido informados de la pendencia del proceso y tenido oportunidad de intervenir en él; pero, aparte de la complejidad que eso introduciría en el proceso. ¿Sería razonable esta exigencia habida cuenta de que quienes han ejercitado la acción judicial son quienes tienen la legitimación que el ordenamiento considera justificada? Una última opción. ¿Se podría hacer depender ese efecto prejudicial de que cada uno de los legitimados, según le convenga, lo invoque o no al pretender la tutela de su interés individual?

6 Convenio Europeo de Derechos Humanos; art. 47 Carta de Derechos Fundamentales de la Unión Europea), o, en fin, como que tiene derecho a la tutela judicial efectiva la persona "cuyos derechos y libertades hayan sido violados" (art. art. 47 Carta de Derechos Fundamentales de la Unión Europea).

${ }^{239}$ Por ejemplo: se realiza una conducta contraria a la libre competencia o una conducta infractora del régimen de condiciones generales de la contratación y, a causa de esas infracciones, cláusulas de una serie de contratos pueden ser consideradas nulas o nacen derechos individuales a indemnización. 
2) En caso de lesión de intereses públicos y/o sociales, si los legitimados "ordinarios" no piden la tutela judicial, los individuos que participan en el disfrute de tales intereses -porque encuentran satisfacción también individual con la satisfacción de los intereses públicos y/o sociales- pueden quedar sujetos a una doble restricción. Por un lado, pueden ver limitada la tutela judicial de sus intereses individuales, si la obtención de la misma está condicionada por el enjuiciamiento previo de un elemento que sólo pueden plantear ante el tribunal los legitimados "ordinarios" para la defensa de intereses públicos y/o sociales ${ }^{240}$. Este obstáculo podría ser eliminado simplemente manteniendo la tradicional acotación subjetiva de la cosa juzgada, que no afectaría a una eventual acción futura de los legitimados para la defensa de intereses públicos y/o sociales ${ }^{241}$. Una segunda restricción afectará a su participación en el disfrute del interés público y/o social: al no producirse la declaración de ilicitud de la conducta, una orden de cesación o de restauración del estado anterior a la conducta infractora -acompañadas de sanciones-, todos los que participan en el disfrute de aquellos intereses continuarán expuestos a la situación de riesgo o de daño efectivo. ¿Estaría justificada en estos casos una legitimación subsidiaria de los individuos? ¿Bajo qué condiciones? ¿Tal vez un previo requerimiento a los legitimados "ordinarios"? Debe ser objeto de especial reflexión hasta qué punto hay razones para autorizar que un particular, con menor o inexistente legitimidad para apreciar los intereses públicos y/o sociales en juego, y, tal vez, técnicamente menos preparado para su defensa en juicio, exponga esos intereses al "riesgo" de la cosa juzgada.

3) La tercera situación es diferente a las anteriores, porque la justificación de matizaciones a la regla general no radica, al menos a primera vista, en la conexión entre intereses públicos y/o sociales con intereses individuales, cada uno de ellos con sus correspondientes legitimados. La justificación, ahora, es doble. De un lado, nos hallamos ante casos en que un número elevado de intereses individuales han sido lesionados por una causa común, pero es probable que cada uno de sus titulares no esté dispuesto a pretender su tutela judicial, porque el coste de la gestión es desproporcionado respecto del eventual resultado que puede obtener. El interés individual no será protegido, pero, además, no podrá, de hecho, hacerse justicia, lo que, en verdad, es también contrario al interés público. Por otro lado, si, en casos de esas características, la tutela judicial lle-

\footnotetext{
240 Así ocurría cuando las acciones sobre validez y eficacia de contratos individuales o sobre indemnizaciones individuales por infracción de normas de defensa de la competencia sólo podían ser ejercitadas previa declaración de esta infracción a instancia de unos específicos legitimados. Y así seguirá ocurriendo en los ordenamientos en los que exista ese condicionamiento prejudicial.

241 Una persona puede pretender la aplicación a su propio contrato del régimen de las condiciones generales de la contratación, aunque quien tenga la legitimación necesaria no haya ejercitado previamente con éxito una acción declarativa de que cierta cláusula contractual es una condición general.
} 
ga a ser pretendida por cada interesado, según la regla general, los tribunales experimentarán una sobrecarga de trabajo con abundantes y similares asuntos de mínimo valor económico, con las consecuencias de una mayor lentitud del conjunto del sistema judicial y de riesgos de contradicción de sus decisiones. Esta alternativa afecta, también, al interés público en que las respuestas judiciales sean coherentes y se den en plazo razonable. En estos casos, la cuestión es si alguien diferente a cada legitimado individual ${ }^{242}$ podría plantear en el proceso las pretensiones de todos o de buena parte de estos, de manera que fuera posible un tratamiento que evitara los defectos apuntados.

Los principales interrogantes están abiertos en la situación que he descrito en último lugar ${ }^{243}$, y versan sobre diversos aspectos de la declaración o la manifestación de la voluntad de los legitimados que, inicialmente, no hubieran acudido al tribunal. La razón es que esa voluntad será relevante para que, a pesar de su inactividad inicial, sus intereses jurídicos individuales (la nulidad de su contrato, el cumplimiento en su favor de una obligación o responsabilidad derivadas de aquél, la indemnización del daño sufrido por cada uno) puedan recibir tutela judicial en el proceso iniciado por otros, pero, también, quedar expuestos al riesgo de que esa protección sea negada.

Menciono muy resumidamente esos aspectos:

1) La forma de la comunicación a esos legitimados de que el proceso que puede afectarles está pendiente. Este tema pertenece al núcleo del derecho a ser oído en juicio, o, de otro modo dicho, a la contradicción procesal o a un proceso justo, pero esto no significa que exista una única solución ajustada a estos criterios fundamentales.

2) Las conductas de esos legitimados ante la comunicación y las consecuencias que la ley procesal vincula a las diferentes conductas. En cuanto a esto, hay una gran alternativa: puede ser requerida una declaración expresa y positiva de cada legitimado para que su interés jurídico individual sea objeto del proceso (opt-in), o puede ser exigida una declaración expresa y negativa para sustraerlo del objeto del proceso ya iniciado (op-out). Ciertamente, el segundo término de la alternativa significa una carga procesal muy severa; pero el primero no

\footnotetext{
242 Podrían serlo la entidad pública o la asociación o los colectivos más informales legitimados para pretender la tutela de intereses públicos y/o sociales, cuya lesión ha sido, a su vez, causa de la lesión de los plurales intereses individuales; o bien alguno o algunos de los titulares de intereses individuales necesitados de tutela judicial.

${ }^{243}$ Véanse, sin pretensiones de exhaustividad, Green Paper on Consumer Collective Redress, apartados 54-57; Hodges, The Reform of Class and Representative Actions in European Legal Systems, pp. 2627, 89-90, 118-125; Hess, "Private law enforcement", p. 72; Caponi, B., "Litisconsorzio "aggregato". L'azione risarciatoria in forma collettiva dei consumatori", en Rivista Trimestrale di Diritto e Procedura Civile, 2008, pp. 827-828; Caponi, B., "La class action in materia di tutela del consumatore in Italia", en II Foro Italiano, novembre 2008, pp. 7-9; Stadler, A., "Group actions as a remedy to enforce consumers interests", en Cafaggi, Micklitz, Eds., New Frontiers of Consumers Protection, pp. 317-318, 327-328.
} 
está libre de una carga notable, como es la de tener que asumir los inconvenientes de una reclamación judicial individual. En cualquier caso, pienso que un criterio importante para elegir en esta alternativa difícil radica en la mayor o menor idoneidad de la forma de comunicación para llegar efectivamente a conocimiento de los legitimados. Tampoco me parece una cuestión de difícil solución la de los requisitos formales de la declaración de voluntad de estos, siempre que se respeten unas garantías que avalen suficientemente la fiabilidad de la autoría y del sentido de esa declaración.

Junto a otras consideraciones que se han expuesto para justificar las mejores soluciones a las cuestiones apuntadas, sería conveniente tener presente que, tradicionalmente, las leyes procesales han atendido a razones diversas tanto para reputar suficientes formas de comunicación aunque no garanticen, plenamente, el conocimiento del interesado, como para establecer cargas procesales con graves consecuencias (renuncia, allanamiento, etc.). En la clase de casos que ahora consideramos, especialmente si la cuantía de las reclamaciones individuales es escasa, concurre la razón potentísima de que la falta de un régimen procesal específico y fácilmente practicable equivaldría a que la tutela judicial de ciertos intereses jurídicos fuera, de hecho, inaccesible ${ }^{244}$.

3) La necesidad de evitar la tramitación separada de muchos procesos con objetos similares, o la necesidad de que, en el supuesto de acumulación de los mismos en un único procedimiento, éste pueda ser tramitado con suficiente agilidad, pueden conducir a una restricción de los derechos procesales de cada una de las personas que es parte. Desde la perspectiva de estos derechos me parece menos defendible la imposición a esas personas de la actuación procesal por medio de una única defensa jurídica, que la aplicación de la técnica del proceso-modelo o proceso-testigo. Esta técnica no impide el ejercicio de los derechos procesales individuales, porque no excluye que los procesos inicialmente suspendidos se desarrollen después de la sentencia del proceso-modelo. ${ }^{245}$ Tampoco viola el derecho a un proceso sin dilaciones indebidas, porque la dilación que impone está justificada y, por otro lado, porque dilaciones importantes serían precisamente inevitables si esta técnica no fuera aplicada.

\footnotetext{
244 Green Paper on Consumer Collective Redress, apartado 9; Hodges, The reform of Class and Representative Actions, pp. 88-89, 129; Caponi, "Litisconsorzio "aggregato". L'azione risarciatoria in forma collettiva", p. 821; Stadler, "Group actions as a remedy to enforce consumers interests", pp. 325-327.

245 Es cierto que puede disuadir, de hecho, de que se opte por la continuación de los procesos suspendidos, bien sea porque la sentencia del proceso-modelo genera una clara perspectiva de fracaso para los procesos que continúen, bien sea porque el devenir de aquel proceso haya conducido a atractivas soluciones transaccionales a las que convenga adherirse.
} 
C) La igualdad en la ley en cuanto a los medios para la protección judicial de los derechos e intereses jurídicos supraindividuales

Empiezo advirtiendo que no es, estrictamente, una exigencia del principio de igualdad de trato en la ley que ésta dote de una ordenación específica y, además, de una ordenación igual, a todos los supuestos en los que estén en juego intereses supraindividuales. La libertad de configuración normativa, que constitucionalmente corresponde al legislador, justifica que éste pueda elegir entre diversas opciones para la protección judicial de derechos e intereses supraindividuales.

No obstante, desde un punto de vista técnico-jurídico ${ }^{246}$, el crecimiento de la litigiosidad relativa a esa clase de intereses jurídicos justifica una ordenación que atienda al conjunto de ese fenómeno y que de soluciones coherentes con esa consideración de conjunto. Por esta proximidad con el criterio constitucional enunciado al principio, me permito reunir en este apartado algunas consideraciones en las que la atención al criterio de igualdad en la ley conduce, por cierto, a resultados bastante divergentes.

Por un lado se plantea la cuestión de las normas sobre legitimación activa y modalidades de tutela judicial que pueden obtener los legitimados, en supuestos en que están en juego intereses supraindividuales ${ }^{247}$. Es comprensible que, en las etapas iniciales de una nueva realidad social, los legisladores opten por establecer normas sólo referidas a aquellas materias jurídicas que han sido las primeras en experimentar la necesidad de regulación. No obstante, las características del Derecho privado actual y su utilización masiva en las relaciones sociales generalizan la necesidad de una regulación adecuada de aquellas cuestiones básicas para el acceso a la protección judicial.

Sin embargo, hay otras materias procesales respecto de las cuales también se han establecido, o se proyectan, normas especiales para litigios relativos a intereses supraindividuales que, precisamente desde el criterio de la igualdad en la ley, no es tan seguro que deban generalizarse en esa clase de litigios o sólo en ella. Me refiero a temas como la facilitación del acceso a los medios de prueba, la facilitación de los resultados probatorios ${ }^{248}$, la posibilidad de recurso ante el más alto tribunal ordinario ${ }^{249}$, el fortalecimiento de la tutela judicial -con medidas provisionales efectivas y con instrumentos también efectivos al servicio

246 Hess, "Private law enforcement", p. 74, invoca, justamente, la conservación de "die Kohärenz und Ordnungsfunktion der Kodification für die Zivilprozess".

247 Véase supra apartado IV.2.

248 Véase supra apartado IV.4.

249 Véase supra apartado IV.5. 
de la tutela judicial ejecutiva-, ${ }^{250}$ y los costes del proceso y su financiación ${ }^{251}$, Las normas sobre estas materias deberían ser las adecuadas para que el proceso civil fuera más efectivo, pero en general, no sólo en determinadas clases de liti$\operatorname{gios}^{252}$. Y si hubiera que establecer normas especiales éstas deberían justificarse por las características objetivas de los asuntos litigiosos y no solamente por la calidad de los intereses jurídicos en juego.

\section{Una nota final sobre la "medición" de la eficiencia de las modalidades de enforcement}

Es un objetivo lógico de las ciencias sociales diseñar métodos que posibiliten una evaluación cada vez más precisa de la eficiencia de las modalidades de law enforcement $t^{253}$. Por otra parte, es legítimo exigir que las opciones políticas sean adoptadas tomando en cuenta esas evaluaciones.

No obstante, mientras las herramientas de evaluación se perfeccionan -e, incluso, cuando pueda pensarse que son perfectas-, considero que las opciones políticas deben estar orientadas por una sana duda sobre su fiabilidad para predecir los resultados, porque la gravedad de unos resultados erróneos puede, fácilmente, tener una entidad desproporcionada en comparación con los costes de un reforzamiento de las actuaciones preventivas de los poderes públicos.

En la elaboración de esta ponencia, frecuentemente me he encontrado ante la duda de si es más eficiente un sistema de administrative enforcement-dotado de medios suficientes y correctamente gestionado- o uno de judicial enforcement -igualmente bien ordenado, habilitado para adoptar medidas preventivas y para imponer indemnizaciones de cuantías disuasorias, que, eso sí, actuaría a instancia de particulares afectados por un daño inminente o actual-. Esa valoración comparativa de la eficiencia se hace, en efecto, con base en buenos datos, en malos datos, o sin datos. ${ }^{254}$ Como máximo, he llegado a convencerme de que es más eficiente que los sistemas de enforcement se complementen y que la legitimación para pedir la tutela de los tribunales civiles sea atribuida de manera que no haya resquicios en

\footnotetext{
${ }^{250}$ Véase supra apartado IV.6.

251 Véase supra apartado IV.7.

252 Esta reflexión aparece con frecuencia en las aportaciones de Hodges, "Competition Enforcement", p. 1400-1401; Hodges, The reform of Class and Representative Actions, pp. 51-54, 184, 189-190.

253 Considero imposible que pueda llegarse a una "medición" o cálculo" de esa eficiencia, porque en la aplicación del Derecho siempre inciden componentes no mensurables que, por esa razón, no podrían ser integrados en el modelo de "cálculo".

${ }^{254}$ Sobre la comparación de la eficiencia de los sistemas de enforcement-especialmente del Derecho de la competencia- y la importancia de los datos para fundar las valoraciones, Hodges, "Competition Enforcement", p. 1385, y, del mismo autor, The reform of Class and Representative Actions, pp. 137-139, 175-177, 194-202; Eger, Weise, "Limits to the private enforcement of antitrust law"; Alfaro, "Contra la armonización positiva". Más en general, véanse los autores citados en nota 225.
} 
la protección del interés público, de los intereses sociales, así como tampoco de los intereses individuales homogéneos cuyo acceso a la protección judicial esté cerrado por la fuerza de los hechos, no por la libre decisión de sus titulares.

Casualmente, durante la elaboración de esta ponencia -es decir, en el tiempo histórico que ha enmarcado mi trabajo- ha ocurrido un acontecimiento que debe ser tenido muy en cuenta al afrontar aquella duda: la crisis financiera y económica de mayor gravedad desde la de 1929. Reflexiones muy autorizadas sobre las causas de esta crisis han puesto de manifiesto la decisiva influencia del debilitamiento de la regulación por los poderes públicos ${ }^{255}$. Unos interpretarán que esa reducción de la presencia de los poderes públicos fue el fruto de una estricta opción ideológica, otros argumentarán que las consecuencias negativas sólo significan una fisura en una opción técnica que, por lo general, es consistente y debe mantenerse. El hecho irrebatible es que los resultados indeseables se han producido, y que los enormes costes para corregirlos y para minimizar su alcance han tenido que ser asumidos por los Estados y, en definitiva, por los ciudadanos. Ésta es una buena oportunidad para verificar, confrontando las teorías con un referente empírico inmediatamente disponible, si la opción de reducir la intervención del poder público -con el consiguiente ahorro presupuestario-fue, o no, la más acertada en atención a criterios de eficiencia. Además, es conveniente no desaprovechar esta oportunidad, porque si se da ocasión para que se repita un acontecimiento similar las consecuencias pueden ser letales, y no sólo para la economía ${ }^{256}$.

\footnotetext{
${ }^{255}$ Me refiero, en primer lugar, a The Financial Crisis Inquiry Report. Final Report of the National Commission on the Causes of the Financial and Economic Crisis in The United States, January 2011. Available at http:// fcic.law.stanford.edu. De esste informe destaco las pp. XVIII y XXII-XXIII de las conclusiones, las pp. 13, 28, 33-36, 47-48, los capítulos IV y XII, y las pp. 307-308. Véase, también, el informe de la Independent Evaluation Office of International Monetary Fund, IMF Performance in the Run-Up to the Financial and Economic Crisis: IMF Surveillance in 2004-07, January 10, 2011. Available at http://www.ieo-imf.org/pub/issues.html. De este informe tienen especial interés el resumen ejecutivo y los apartados 2, 11, 13, 24, 25 y 34.

256 Alguien -permítaseme apostillar- tan poco revolucionario como Jean Claude Trichet, decía en una intervención que tuvo en Madrid, el 13 de mayo de 2011, con el título Financial reform: what has been achieved and what remains to be done, que: "Thanks, in particular, to prompt and resolute action by central banks and by governments, the international community avoided a great depression, after the intensification of the crisis in mid-September 2008. With the global recovery being confirmed, numerous voices in the financial sector are arguing that we are now back to business as usual. Achieving an ambitious programme of reforms of rules, regulations and oversight of the financial sector is considered by some as unnecessary and counterproductive. I do not at all share those views. It is an absolute obligation, for all of us, to do all what is necessary to reinforce the resilience of the financial system and ensure its sustainable contribution to growth. We must be sure that the excessive fragility that was revealed in 2008 and 2009 is eliminated. Not only because the costs of financial crises in terms of growth is always considerable but, even more, because it is extremely likely that our democracies would not be ready to provide once again the financial commitments to avoid a great depression in case of a new crisis of the same nature. Our people would not permit, for a second time, that governments mobilize $27 \%$ of GDP of tax payer risk, on both sides of the Atlantic, to avoid the collapse of the financial sector (la cursiva es de MOR)". Available at http://www.ecb.int/press/key/date/2011/html/sp110513.en.html
} 
